\title{
New England Faculty and College Students Differ in Their Views About Evolution, Creationism, Intelligent Design, and Religiosity
}

\author{
Guillermo Paz-y-Miño C. • Avelina Espinosa
}

Published online: 18 December 2010

(C) Springer Science+Business Media, LLC 2010

\begin{abstract}
Public acceptance of evolution in Northeastern U.S. is the highest nationwide, only $59 \%$. Here, we compare perspectives about evolution, creationism, intelligent design (ID), and religiosity between highly educated New England faculty $(n=244 ; 90 \%$ Ph.D. holders in 40 disciplines at 35 colleges/universities) and college students from public secular $(n=161)$, private secular $(n=298)$, and religious $(n=185)$ institutions: $94 / 3 \%$ of the faculty vs. $64 / 14 \%$ of the students admitted to accepting evolution openly and/or privately, and $82 / 18 \%$ of the faculty vs. $58 /$ $42 \%$ of the students thought that evolution is definitely true or probably true, respectively. Only $3 \%$ of the faculty vs. $23 \%$ of the students thought that evolution and creationism are in harmony. Although $92 \%$ of faculty and students thought that evolution relies on common ancestry, one in every four faculty and one in every three students did not know that humans are apes; $15 \%$ of the faculty vs. $34 \%$ of the students believed, incorrectly, that the origin of the human mind cannot be explained by evolution, and $30 \%$ of the faculty vs. $72 \%$ of the students was Lamarckian (believed in inheritance of acquired traits). Notably, 91\% of the faculty was very concerned $(64 \%)$ or somehow concerned $(27 \%)$ about the controversy evolution vs creationism vs ID and its implications for science education: $96 \%$ of the faculty vs. $72 \%$ of the students supported
\end{abstract}

G. Paz-y-Miño C.

Department of Biology, University of Massachusetts Dartmouth, 285 Old Westport Road,

North Dartmouth, MA 02747-2300, USA

\footnotetext{
A. Espinosa $(\triangle)$

Department of Biology, Roger Williams University,

One Old Ferry Road,

Bristol, RI 02809, USA

e-mail: aespinosa@rwu.edu
}

the exclusive teaching of evolution while $4 \%$ of the faculty vs. $28 \%$ of the students favored equal time to evolution, creationism and ID; $92 \%$ of the faculty vs. $52 \%$ of the students perceived ID as not scientific and proposed to counter evolution or as doctrine consistent with creationism. Although $\approx 30 \%$ of both faculty and students considered religion to be very important in their lives, and $\approx 20 \%$ admitted to praying daily, the faculty was less religious (Religiosity Index faculty $=0.5$ and students $=0.75$ ) and, as expected, more knowledgeable about science (Science Index faculty $=2.27$ and students $=1.60$ ) and evolution (Evolution Index faculty $=2.48$ and students $=1.65$ ) than the students. Because attitudes toward evolution correlate (1) positively with understanding of science/evolution and (2) negatively with religiosity/political ideology, we conclude that science education combined with vigorous public debate should suffice to increase acceptance of naturalistic rationalism and decrease the negative impact of creationism and ID on society's evolution literacy.

Keywords Assessment · College education · Controversy science versus popular belief

\section{Introduction}

Forty percent of Americans accept the concept of evolution (Miller et al. 2006; The Gallup Poll 2009). In the intellectually progressive Northeastern U.S., favorable views toward evolution only reach 59\%, the highest score nationwide (The Pew Research Center for the People \& the Press 2005). Creationism and intelligent design split the public's support to evolution in the U.S. and nourish the controversy between scientific knowledge and popular belief (Padian 2009; Padian and Matzke 2009; Forrest 
2010; Matzke 2010). The U.S. ranks 33rd in a list of 34 other countries where acceptance of evolution has been polled, in contrast to Iceland, Denmark, Sweden, France, Japan, and the UK, top in the list where $\approx 75-85 \%$ of adults accept evolution (Miller et al. 2006).

The concept of evolution provides naturalistic explanations about the origin of life, its diversification and biogeography, and the synergistic phenomena resulting from the interaction between life and the environment (Paz-y-Miño C. and Espinosa 2009a, b); mutations, gene flow, genetic drift, and natural selection shape life's biological processes in Earth's ecosystems (Mayr 2001). Since the publication of The Origin of Species by Charles Darwin, in 1859, Darwinian evolution has been scrutinized experimentally; today the theory of evolution is widely accepted by the scientific community (Coyne 2009; Dawkins 2009). In contrast, creationism, theistic evolution, creation science, or young-earth creationism (Petto and Godfrey 2007; Matzke 2010; Phy-Olsen 2010) rely on supernatural causation to explain the origin of the universe and life. These views are not recognized by scientists as evidence-based explanations of cosmic processes (Padian 2009; Scott 2009; Paz-y-Miño C. and Espinosa 2009a, b).

The doctrine of intelligent design (ID), born in the 1980s proposes that a Designer is responsible, ultimately, for the assemblage of complexity in biological systems; according to ID, evolution cannot explain holistically the origin of the natural world, nor the emergence of intricate molecular pathways essential to life, nor the huge phylogenetic differentiation of life, and instead ID proposes an intelligent agent as the ultimate cause of nature (Forrest and Gross 2007a, b; Young and Edis 2004; Miller 2007, 2008; PhyOlsen 2010). In 2005, ID was exposed in court (Dover, Pennsylvania, Kitzmiller et al. versus Dover School District et al. 2005; Padian and Matzke 2009; Wexler 2010) for violating the rules of science by "invoking and permitting supernatural causation" in matters of evolution, and for "failing to gain acceptance in the scientific community." Today, "design creationism" (as we also refer to it due to its designer/creator-based foundations) although defeated by science and in the courts, grows influential in the U.S., Europe, Australia, and South America (Cornish-Bowden and Cárdenas 2007; Padian 2009; Forrest 2010; Matzke 2010; Wexler 2010).

Acceptance of evolution among the general public, high schools students and teachers, college students, and scientists has been documented (Bishop and Anderson 1990; Downie and Barron 2000; Moore and Kraemer 2005; Miller et al. 2006; Donnelly and Boone 2007; Moore 2007; Berkman et al. 2008; Hokayem and BouJaoude 2008; Coalition of Scientific Societies 2008; The Gallup Poll 2008, 2009; Paz-y-Miño C. and Espinosa 2009a, b), little is known, however, about tendencies of acceptance of evolution by highly educated audiences, like university professors. A cultural assumption is that such audiences are consistently supportive of science and remain distant from belief-based perspectives about the natural world (but see Ecklund and Scheitle 2007; Gross and Simmons 2009). Here, we examine the views of New England faculty $(n=$ 244) from 35 colleges and universities, who were polled in three areas: (1) the controversy over evolution versus creationism versus ID, (2) their understanding of how the evolutionary process works, and (3) their personal convictions concerning the evolution and/or creation of humans in the context of their own religiosity. We compared and contrasted the faculty's perspectives with those of students from three representative New England institutions: public secular $(n=161)$, private secular $(n=$ $298)$, and religious $(n=185)$. Assessing faculty's versus students' perception of evolution in one of the historically most progressive regions of the U.S. is crucial for determining the magnitude of the impact of creationism and ID on attitudes toward science, reason, and education in science. The New England states have among the highest evolution education standards in the U.S. (letter grade for coverage of evolution in state science standards: Connecticut $D$, Maine $C$, Massachusetts $B$, New Hampshire $A$, Rhode Island $B$, Vermont $B$; Mead and Mates 2009); however, only two out of three New Englanders accept evolution (above). By understanding opinions about evolution among "highly educated" versus "in-the-process-ofacquiring-education" audiences, we aim at improving the approach with which evolution and science are communicated to the public, contributing to curricular/pedagogical reform for their effective teaching in college, and minimizing the negative effects of creationism and ID on the U.S. educational system (Paz-y-Miño C. and Espinosa 2009a, b).

\section{Methods}

We sampled 35 academic institutions (17 colleges and 18 universities) widely distributed geographically in all New England states (Connecticut, Maine, Massachusetts, New Hampshire, Rhode Island and Vermont; Table 1). In each state, we selected two public secular, two private secular, and two religious colleges and/or universities, except for Maine where only one religious institution was identified (Table 1). We contacted via email (addresses obtained from institutional websites) 992 faculty according to two criteria: first, members of the biology departments, or close equivalents (e.g., ecology and evolutionary biology, molecular and cell biology, and natural sciences), of each institution (regardless of sex), who are usually highly educated in evolution; and second, a similar number of 
nonbiology faculty, across some 40 different disciplines, who were selected randomly (sex ratio 1:1; Table 1). To compare New England faculty views with those of college students, we surveyed students from three representative New England institutions (email requests to all enrolled students): public secular University of Massachusetts Dartmouth
(UMassD Pub, 7,982 students contacted), private secular Roger Williams University (RWU Priv, 3,806 students contacted), and religious Providence College (PC Rel, 3,910 students contacted) (Table 2). Both faculty and student profiles of those who responded to the survey were comparable in respect to residency and workplace location

Table 1 New England institutions sampled in the study

\begin{tabular}{|c|c|c|c|c|c|c|c|c|c|c|}
\hline \multirow[t]{3}{*}{ State/Institution (type) ${ }^{\mathrm{a}}$} & \multicolumn{5}{|c|}{ Faculty contacted } & \multicolumn{5}{|c|}{ Faculty responders } \\
\hline & \multirow[t]{2}{*}{ No. ${ }^{b}$} & \multicolumn{2}{|l|}{ Biologists } & \multicolumn{2}{|c|}{ Nonbiologists $^{\mathrm{c}}$} & \multirow[t]{2}{*}{ No. } & \multirow{2}{*}{$\begin{array}{l}\% \text { per } \\
\text { subtotal } \\
\text { state })^{\mathrm{d}}\end{array}$} & \multirow{2}{*}{$\begin{array}{l}\% \text { of total } \\
\text { responders }\end{array}$} & \multirow[t]{2}{*}{$\mathrm{F}(\%)^{\mathrm{e}}$} & \multirow[t]{2}{*}{$\mathrm{M}(\%)^{\mathrm{c}}$} \\
\hline & & $\mathrm{F}(\%)$ & $\mathrm{M}(\%)$ & $\mathrm{F}(\%)$ & M (\%) & & & & & \\
\hline \multicolumn{11}{|l|}{ Connecticut (CT) } \\
\hline University of Connecticut (Pub) & 67 & 11 & 22 & 17 & 17 & NA & NA & NA & NA & NA \\
\hline University of Hartford (Pub) & 14 & 2 & 5 & 3 & 4 & NA & NA & NA & NA & NA \\
\hline Yale University (Priv) & 18 & 6 & 3 & 5 & 4 & NA & NA & NA & NA & NA \\
\hline Quinnipiac University (Priv) & 30 & 7 & 8 & 7 & 8 & NA & NA & NA & NA & NA \\
\hline Fairfield University (Rel Catholic) & 24 & 7 & 5 & 6 & 6 & NA & NA & NA & NA & NA \\
\hline Albertus Magnus College (Rel Catholic) & 6 & 1 & 2 & 1 & 2 & NA & NA & NA & NA & NA \\
\hline Subtotal CT & 159 & $34(21.4)^{\mathrm{d}}$ & $45(28.3)^{\mathrm{d}}$ & $39(24.5)^{\mathrm{d}}$ & $41(25.8)^{\mathrm{d}}$ & 38 & $23.9^{\mathrm{d}}$ & $15.6^{\mathrm{e}}$ & NA & NA \\
\hline \multicolumn{11}{|l|}{ Maine (ME) } \\
\hline University of Southern Maine (Pub) & 34 & 5 & 12 & 8 & 9 & NA & NA & NA & NA & NA \\
\hline University of Maine Orono (Pub) & 60 & 14 & 16 & 15 & 15 & NA & NA & NA & NA & NA \\
\hline University of New England (Priv) & 24 & 4 & 8 & 6 & 6 & NA & NA & NA & NA & NA \\
\hline Husson University (Priv) & 16 & 4 & 4 & 4 & 4 & NA & NA & NA & NA & NA \\
\hline $\begin{array}{l}\text { St. Joseph's College of Maine } \\
\text { (Rel Catholic) }\end{array}$ & 8 & 3 & 1 & 2 & 2 & NA & NA & NA & NA & NA \\
\hline Subtotal ME & 142 & $30(21.1)^{\mathrm{d}}$ & $41(28.9)^{\mathrm{d}}$ & $35(24.6)^{\mathrm{d}}$ & $36(25.4)^{\mathrm{d}}$ & 38 & $26.8^{\mathrm{d}}$ & $15.6^{\mathrm{e}}$ & NA & NA \\
\hline \multicolumn{11}{|l|}{ Massachusetts (MA) } \\
\hline $\begin{array}{l}\text { University of Massachusetts } \\
\text { Boston (Pub) }\end{array}$ & 50 & 5 & 20 & 12 & 13 & NA & NA & NA & NA & NA \\
\hline Fitchburg State College (Pub) & 26 & 4 & 9 & 7 & 6 & NA & NA & NA & NA & NA \\
\hline Springfield College (Priv) & 18 & 5 & 4 & 5 & 4 & NA & NA & NA & NA & NA \\
\hline Wheaton College (Priv) & 18 & 4 & 5 & 4 & 5 & NA & NA & NA & NA & NA \\
\hline Merrimack College (Rel Catholic) & 14 & 4 & 3 & 3 & 4 & NA & NA & NA & NA & NA \\
\hline Stonehill College (Rel Catholic & 18 & 4 & 5 & 5 & 4 & NA & NA & NA & NA & NA \\
\hline Subtotal MA & 144 & $26(18.1)^{\mathrm{d}}$ & $46(31.9)^{\mathrm{d}}$ & $36(25.0)^{\mathrm{d}}$ & $36(25.0)^{\mathrm{d}}$ & 34 & $23.6^{\mathrm{d}}$ & $14.0^{\mathrm{e}}$ & NA & NA \\
\hline \multicolumn{11}{|l|}{ New Hampshire (NH) } \\
\hline $\begin{array}{l}\text { University of New Hampshire } \\
\text { Durham (Pub) }\end{array}$ & 78 & 11 & 28 & 19 & 20 & NA & NA & NA & NA & NA \\
\hline Plymouth State University (Pub) & 28 & 8 & 6 & 7 & 7 & NA & NA & NA & NA & NA \\
\hline Dartmouth College (Priv) & 59 & 7 & 22 & 15 & 15 & NA & NA & NA & NA & NA \\
\hline Colby-Sawyer College (Priv) & 20 & 5 & 5 & 5 & 5 & NA & NA & NA & NA & NA \\
\hline Rivier College (Rel Catholic) & 8 & 3 & 1 & 2 & 2 & NA & NA & NA & NA & NA \\
\hline St. Anselm College (Rel Catholic) & 22 & 1 & 10 & 6 & 5 & NA & NA & NA & NA & NA \\
\hline Subtotal NH & 215 & $35(16.3)^{\mathrm{d}}$ & $72(33.5)^{\mathrm{d}}$ & $54(25.1)^{\mathrm{d}}$ & $54(25.1)^{\mathrm{d}}$ & 50 & $23.3^{\mathrm{d}}$ & $20.4^{\mathrm{e}}$ & NA & NA \\
\hline \multicolumn{11}{|l|}{ Rhode Island (RI) } \\
\hline University of Rhode Island (Pub) & 32 & 7 & 9 & 8 & 8 & NA & NA & NA & NA & NA \\
\hline Rhode Island College (Pub) & 32 & 8 & 8 & 8 & 8 & NA & NA & NA & NA & NA \\
\hline Brown University (Priv) & 46 & 7 & 16 & 12 & 11 & NA & NA & NA & NA & NA \\
\hline Roger Williams University (Priv) & 30 & 4 & 11 & 8 & 7 & NA & NA & NA & NA & NA \\
\hline Salve Regina University (Rel Catholic) & 10 & 3 & 2 & 3 & 2 & NA & NA & NA & NA & NA \\
\hline Providence College (Rel Catholic) & 28 & 3 & 11 & 6 & 8 & NA & NA & NA & NA & NA \\
\hline Subtotal RI & 178 & $32(18.0)^{\mathrm{d}}$ & $57(32.0)^{\mathrm{d}}$ & $45(25.3)^{\mathrm{d}}$ & $44(24.7)^{\mathrm{d}}$ & 41 & $23.0^{\mathrm{d}}$ & $16.8^{\mathrm{e}}$ & NA & NA \\
\hline
\end{tabular}


Table 1 (continued)

State/Institution (type)

Faculty contacted

No. $^{{ }^{b}} \frac{\text { Biologists }}{F(\%)} \quad$ M (\%) $\frac{\text { Nonbiologists }^{\mathrm{c}}}{\mathrm{F}(\%) \quad \mathrm{M}(\%)}$

Faculty responders

\begin{tabular}{|c|c|c|c|}
\hline No. & $\begin{array}{l}\% \text { per } \\
\text { subtotal } \\
\text { state })^{\mathrm{d}}\end{array}$ & $\begin{array}{l}\% \text { of total } \\
\text { responders }\end{array}$ & $F(\%)^{e}$ \\
\hline
\end{tabular}

Vermont (VT)

University of Vermont-Burlington (Pub)

Castleton State College (Pub)

Middlebury College (Priv)

Norwich University (Priv)

$50 \quad 10$

$20 \quad 4$

$28 \quad 8$

269

Saint Michael's College (Rel Catholic)

Green Mountain College (Rel Methodist)

Subtotal VT

Grand total
203

102

$15436(23.4)^{\mathrm{d}}$

$\begin{array}{llllll}992 & 193(19.5)^{\mathrm{f}} & 302(30.4)^{\mathrm{f}} & 247(24.9)^{\mathrm{f}} & 250(25.2)^{\mathrm{f}} & 244(24.6)^{\mathrm{f}}\end{array}$
NA

NA

NA

NA

NA

NA

$27.9^{\mathrm{d}}$
NA NA NA

NA NA NA

NA NA NA

NA NA NA

NA NA NA

NA NA NA

$17.6^{\mathrm{e}} \quad \mathrm{NA} \quad \mathrm{NA}$

$90(36.9)^{\mathrm{e}} 154(63.1)^{\mathrm{e}}$

${ }^{\mathrm{a}}$ Type of institution refers to public secular (Pub), private secular (Priv) and religious (Rel)

${ }^{\mathrm{b}}$ Faculty were contacted according to two criteria: first, members of the biology departments, or equivalent, of each institution (regardless of sex), who are usually highly educated in evolution; and second, a similar number of nonbiology faculty, across all disciplines, who were selected randomly (sex ratio, 1:1)

${ }^{\mathrm{c}}$ Nonbiologists correspond to random selection of faculty from ca. 40 different disciplines, as follows: CT University of Connecticut $(n=9)$ : Anthropology, Communication Sciences, English, History, Human Development and Family Studies, Linguistics, Philosophy, Political Science, Psychology; University of Hartford ( $n=6)$ : Art History, Communications, Computer Science, Legal Studies, Politics and Government, Sociology; Yale University ( $n=3$ ): Astronomy, Forestry and Environmental Studies, History; Quinnipiac University $(n=4)$ : Business, Computer Science and Interactive Digital Design, Journalism, Public Relations; Fairfield University $(n=4)$ : Education, Philosophy, Political Science, Religious Studies; Albertus Magnus College $(n=2)$ : Mathematics, Psychology. ME University of Southern Maine $(n=6)$ : Chemistry, Environmental Science, Engineering, History, Mathematics and Statistics, Philosophy; University of Maine-Orono ( $n=7)$ : Anthropology, Art, Engineering, International Affairs, Mathematics and Statistics, Nursing, Political Science; University of New England ( $n=5)$ : Business and Communications, English and Language Studies, Global Humanities, Psychology, Women's and Gender Studies; Husson University $(n=3)$ : Business, Education, Legal Studies; Saint Joseph's College of Maine $(n=4)$ : Elementary Education, Criminal Justice, Exercise Science, Theology. MA University of Massachusetts Boston $(n=7)$ : Applied Linguistics, English, History, Mathematics, Political Science, Nursing and Health Sciences, Sociology; Fitchburg State College $(n=4)$ : Economics, History, Industrial Technology, Mathematics; Springfield College $(n=4)$ : Education, Mathematics/Physics and Computer Science, Social Work, Visual and Performing Arts; Wheaton College ( $n=3)$ : Economics, English, Music; Merrimack College $(n=3)$ : Electrical Engineering, Sociology, Religious and Theological Studies; Stonehill College ( $n=4)$ : Business Administration, Economics, Mathematics, Religious Studies. NH University of New Hampshire-Durham ( $n=7)$ : Anthropology, Art and Art History, Education, English, Health Management and Policy, History, Mathematics and Statistics; Plymouth State University $(n=6)$ : Business, Criminal Justice, Economics, Education, Mathematics, Philosophy; Dartmouth College $(n=9)$ : Anthropology, Computer Science, Economics, Engineering Science, English, Geography, Mathematics, Physics and Astronomy, Women's and Gender Studies; Colby-Sawyer College $(n=4)$ : Business Administration, Education, Psychology, Social Science; Rivier College $(n=3)$ : Business Administration, Nursing, Psychology; St. Anselm College $(n=3)$ : English, History, Humanities. RI University of Rhode Island ( $n=4)$ : Chemistry, English, Nursing, Journalism; Rhode Island College $(n=6)$ : Art, Communications, English, History, Philosophy, Physical Sciences; Brown University $(n=8)$ : Anthropology, Education, History, Philosophy, Political Sciences, Psychology, Sociology, Visual Arts; Roger Williams University $(n=11)$ : Architecture, Chemistry, Communications, Computer Sciences, Creative Writing, Dance, English, History, Political Sciences, Psychology, Theater; Salve Regina University $(n=3)$ : Anthropology, Business Studies, Religious and Theological Studies; Providence College $(n=8)$ : Art History, English, History, Philosophy, Political Science, Psychology, Secondary Education, Sociology. VT University of VermontBurlington ( $n=9)$ : Anthropology, Biochemistry, Education, Engineering, English, Geology, Mathematics and Statistics, Molecular Physiology and Biophysics, Physics; Castleton State College $(n=4)$ : Business Administration, Sociology/Social Work and Criminal Justice, Music, Natural Sciences; Middlebury College $(n=4)$ : Economics, Education Studies, Geography, Religion; Norwich University $(n=6)$ : Chemistry and Biochemistry, Geology and Environmental Science, Mathematics, Nursing, Physics, Sports Medicine; Saint Michael's College $(n=5)$ : Computer Science, Economics, History, Political Science, Sociology and Anthropology; Green Mountain College $(n=3)$ : Environmental Studies, Communications and Journalism, History

${ }^{\mathrm{d}}$ Percentage estimated in respect to subtotal number of faculty contacted per state

${ }^{\mathrm{e}}$ Percentage estimated in respect to total number of faculty responding to the survey $(N=244)$

${ }^{\mathrm{f}}$ Percentage estimated in respect to grand total number of faculty contacted to participate in the survey $(N=992)$

(New England states), but differed, as we expected, in respect to place of birth (faculty usually belong to diverse cultural backgrounds: New England 42.6\%, East Coast $17.6 \%$, other states $27.5 \%$, foreign countries $12.3 \%$; students mean Pub+Priv+Rel: New England $78 \%$, East Coast $14 \%$, other states $5 \%$, foreign countries $3 \%$; Table 2) and level of education (faculty: Ph.D. holders $90.2 \%$, doctoral degree or equivalent $2.9 \%$, masters degree $6.9 \%$; students mean Pub+Priv+Rel: freshman $19.4 \%$, sophomore $17.4 \%$, junior $16.7 \%$, senior 19.0\%; Table 2).

Eight hundred and eighty-eight faculty $(n=244$, $27.5 \%)$ and students $(n=644,72.5 \%)$ responded to an 11-question anonymous and voluntary online survey to 
Table 2 Profile of faculty and students from public secular, private secular, and religious institutions who participated in the study

\begin{tabular}{|c|c|c|c|c|c|c|c|c|c|c|}
\hline & \multirow{2}{*}{\multicolumn{2}{|c|}{ Faculty }} & \multicolumn{8}{|c|}{ Students } \\
\hline & & & \multicolumn{2}{|c|}{ Public secular } & \multicolumn{2}{|c|}{ Private secular } & \multicolumn{2}{|c|}{ Religious } & \multicolumn{2}{|c|}{ Grand total } \\
\hline & No. & $\%$ & No. & $\%$ & No. & $\%$ & No. & $\%$ & No. & $\%^{\mathrm{a}}$ \\
\hline Total & 244 & $27.5^{\mathrm{a}}$ & 161 & $18.1^{\mathrm{a}}$ & 298 & $33.6^{\mathrm{a}}$ & 185 & $20.8^{\mathrm{a}}$ & 888 & $100^{\mathrm{a}}$ \\
\hline Females & 90 & $36.9^{\mathrm{b}}$ & 96 & $59.6^{\mathrm{b}}$ & 185 & $62.1^{\mathrm{b}}$ & 111 & $60.0^{\mathrm{b}}$ & 482 & $54.3^{\mathrm{a}}$ \\
\hline Males & 154 & $63.1^{\mathrm{b}}$ & 65 & $40.4^{\mathrm{b}}$ & 113 & $37.9^{\mathrm{b}}$ & 74 & $40.0^{\mathrm{b}}$ & 406 & $45.7^{\mathrm{a}}$ \\
\hline $\mathrm{PhD}$ degree & 220 & $90.2^{\mathrm{b}}$ & NA & NA & NA & NA & NA & NA & 220 & $24.8^{\mathrm{a}}$ \\
\hline Doctorate degree & 7 & $2.9^{\mathrm{b}}$ & NA & NA & NA & NA & NA & NA & 7 & $0.8^{\mathrm{a}}$ \\
\hline Masters degree & 17 & $6.9^{\mathrm{b}}$ & NA & NA & NA & NA & NA & NA & 17 & $1.9^{\mathrm{a}}$ \\
\hline Freshman & NA & NA & 49 & $30.4^{\mathrm{b}}$ & 79 & $26.5^{\mathrm{b}}$ & 44 & $23.8^{\mathrm{b}}$ & 172 & $19.4^{\mathrm{a}}$ \\
\hline Sophomore & NA & NA & 46 & $28.6^{\mathrm{b}}$ & 67 & $22.5^{\mathrm{b}}$ & 42 & $22.7^{\mathrm{b}}$ & 155 & $17.4^{\mathrm{a}}$ \\
\hline Junior & NA & NA & 28 & $17.4^{\mathrm{b}}$ & 70 & $23.5^{\mathrm{b}}$ & 50 & $27.0^{\mathrm{b}}$ & 148 & $16.7^{\mathrm{a}}$ \\
\hline Senior & NA & NA & 38 & $23.6^{\mathrm{b}}$ & 82 & $27.5^{\mathrm{b}}$ & 49 & $26.5^{\mathrm{b}}$ & 169 & $19.0^{\mathrm{a}}$ \\
\hline New England & 104 & $42.6^{\mathrm{b}, \mathrm{c}}$ & 146 & $90.7^{\mathrm{b}, \mathrm{g}}$ & 223 & $74.8^{\mathrm{b}, \mathrm{k}}$ & 124 & $67.0^{\mathrm{b}, \mathrm{o}}$ & 597 & $67.2^{\mathrm{a}}$ \\
\hline East Coast & 43 & $17.6^{\mathrm{b}, \mathrm{d}}$ & 6 & $3.7^{\mathrm{b}, \mathrm{h}}$ & 57 & $19.1^{\mathrm{b}, 1}$ & 38 & $20.5^{\mathrm{b}, \mathrm{p}}$ & 144 & $16.2^{\mathrm{a}}$ \\
\hline Other states & 67 & $27.5^{\mathrm{b}, \mathrm{e}}$ & 4 & $2.5^{\mathrm{b}, \mathrm{i}}$ & 10 & $3.4^{\mathrm{b}, \mathrm{m}}$ & 16 & $8.7^{\mathrm{b}, \mathrm{q}}$ & 97 & $10.9^{\mathrm{a}}$ \\
\hline Foreign countries & 30 & $12.3^{\mathrm{b}, \mathrm{f}}$ & 5 & $3.1^{\mathrm{b}, \mathrm{j}}$ & 8 & $2.7^{\mathrm{b}, \mathrm{n}}$ & 7 & $3.8^{\mathrm{b}, \mathrm{r}}$ & 50 & $5.7^{\mathrm{a}}$ \\
\hline
\end{tabular}

${ }^{a}$ Percentages in respect to grand total number of participants or "responders" to the survey $(n=888)$, which is a fraction of the number of faculty $(n=992)$ plus students (public $=7,982$; private $=3,806$; and religious $=3,910$ ) contacted via email and asked to take part in the study

${ }^{\mathrm{b}}$ Percentages in respect to total number of participants per group of faculty or college students from public secular, private secular or religious institutions

${ }^{\mathrm{c}}$ New England faculty natives correspond to MA, $13.7 \%$; CT, 6.8\%; VT, 6.8\%; ME, 5.9\%; NH, $4.9 \%$; and RI, $4.5 \%$

${ }^{\mathrm{d}}$ East Coast faculty natives correspond to NY, 9.6\%; PA, 4.4\%; NJ, 2.4\%; and MD and VA, $\approx 1.2 \%$

${ }^{\mathrm{e}}$ Other states faculty natives correspond to CA, 7.3\%; MI, 3.6\%; CO and TX, 2.5\%; IL, 2.0\%; OH, 1.6\%; and 17 other states plus Puerto Rico, $10.5 \%$

${ }^{\mathrm{f}}$ Foreign countries faculty correspond to 15 nationalities (Europe and UK, 7.6\%; Canada, 2.4\%; and Australia, China, Libya, and Brazil, 2.3\%)

${ }^{\mathrm{g}}$ New England students at public secular institution were natives from MA, $86.9 \%$; RI, $2.8 \%$; and CT, $<1 \%$

${ }^{\mathrm{h}}$ East Coast students at public secular institution were natives from NY, $2.7 \%$; $\mathrm{NJ}$ and $\mathrm{VA},<1 \%$

${ }^{\mathrm{i}}$ Other states students at public secular institution were natives from four states AZ, FL, MI, and TX, 2.5\%

${ }^{\mathrm{j}}$ Foreign countries students at public secular institution correspond to four nationalities (Cape Verde, Cameroon, Philippines, and Brazil, 3.1\%)

${ }^{\mathrm{k}}$ New England students at private secular institution were natives from MA, 29.1\%; CT, 19.4\%; RI, 15.5\%; NH, 6.6\%; VT, 2.8; ME, $1.4 \%$

${ }^{\mathrm{i}}$ East Coast students at private secular institution were natives from NY, 9.7\%; NJ, 5.1\%; PA, 2.2\%; MD, 1.1\%; VA, <1\%

${ }^{\mathrm{m}}$ Other states students at private secular institution were natives from nine states CA, CO, GA, IL, IN, KT, MI, TN, and WA, 3.4\%

${ }^{\mathrm{n}}$ Foreign countries students at private secular institution correspond to eight nationalities (France, Ghana, India, Korea, Lebanon, Peru, Romania, and UK, $2.7 \%)$

${ }^{\mathrm{o}}$ New England students at religious institution were natives from MA, 37.2\%; CT, $11.2 \%$; RI, 14.1\%; NH, 2.0\%; ME, $1.5 \%$; VT, $<1 \%$

${ }^{\mathrm{p}}$ East Coast students at religious institution were natives from NY, 10.2\%; NJ, 6.8\%; PA, 2.5\%; DE and VA, $1.0 \%$

${ }^{\mathrm{q}}$ Other states students at religious institution were natives from 11 states CA, FL, IL, IN, MN, MO, OH, OR, SC, TN, and TX, 8.7\%

${ }^{\mathrm{r}}$ Foreign countries students at religious institution correspond to seven nationalities (Bosnia, Canada, Ghana, Korea, Latvia, Portugal, and Zimbabwe, $3.8 \%)$

assess their views about evolution, creationism, and intelligent design (questions $1-7$, below), as well as about their understanding of how the evolutionary process works (Questions 8-9, below), and their personal convictions concerning both the evolution and/or creation of humans and degree of religiosity (Questions 10-11, below). All participants were free to withdraw from the survey at any time; no risks or discomfort were involved in the study. The Institutional Review Board of UMassD approved the New England faculty (surveyed during the first week of April and third week of May 2010) and UMassD students' study (second week of September 2009), and the Human Subjects/Institutional Review Boards of RWU (third week of October 2009) and PC (third week of April 2009) approved the surveying of their own students. All participants answered questions 1-11 (but see exceptions below) in order and were instructed to not skip or go back to previous questions to fix and/or compare answers. Questions 1-7 and 10 had five (A, B, C, D, or E) or three (A, B, or C) choices per question, respectively; Questions 8-9 and 11 were true/false and had five (A, B, C, D, or E) or three (A, B, or C) subcomponents (each true/false), 
respectively. All choices per question, including the true/ false options, were presented randomly and only one choice was possible per question, except for question 11 that allowed responders to select as many as three choices. For the purpose of reporting the data in this article and matching the description of each question with the figure legends (results, below), here we state the questions as follows:

Questions Addressing Views About Evolution, Creationism, and ID

Question 1 Evolution, creationism, and intelligent design in the science class. Which of the following explanations about the origin and development of life on Earth should be taught in science classes? $\mathrm{A}=$ evolution, $\mathrm{B}=$ equal time to evolution, creationism, intelligent design, $\mathrm{C}=$ creationism, $\mathrm{D}=$ intelligent design, and $\mathrm{E}=$ do not know enough to say.

Question 2 ID. Which of the following statements is consistent with ID? A=ID is not scientific but has been proposed to counter evolution based on false claims, $\mathrm{B}=\mathrm{ID}$ is religious doctrine consistent with creationism, $\mathrm{C}=$ no opinion, $\mathrm{D}=\mathrm{ID}$ is a scientific alternative to evolution and of equal scientific validity among scientists, and $\mathrm{E}=\mathrm{ID}$ is a scientific theory about the origin and evolution of life on Earth.

Question 3 Evolution and your reaction to it. Which of the following statements fits best your position concerning evolution? A=hearing about evolution makes me appreciate the factual explanation about the origin of life on Earth and its place in the universe, $\mathrm{B}=$ hearing about evolution makes no difference to me because evolution and creationism are in harmony, $\mathrm{C}=$ hearing about evolution makes me uncomfortable because it is in conflict with my faith, $\mathrm{D}=$ hearing about evolution makes me realize how wrong scientists are concerning explanations about the origin of life on Earth and the universe, and $\mathrm{E}=\mathrm{do}$ not know enough to say.

Question 4 Your position about the teaching of human evolution. With which of the following statements do you agree? $\mathrm{A}=\mathrm{I}$ prefer science courses where evolution is discussed comprehensively and humans are part of it, $\mathrm{B}=\mathrm{I}$ prefer science courses where plant and animal evolution is discussed but not human evolution, $\mathrm{C}=\mathrm{I}$ prefer science courses where the topic evolution is never addressed, $\mathrm{D}=\mathrm{I}$ avoid science courses with evolutionary content, and $\mathrm{E}=$ do not know enough to say.

Question 5 Evolution in science exams. Which of the following statements fits best your position concerning science exams? A=faculty: instructors should have no problem giving exams with questions concerning evolution, or students: I have no problem answering questions concerning evolution, $\mathrm{B}=$ science exams should always include some questions concerning evolution, $\mathrm{C}=$ faculty: students should prefer to not answer questions concerning evolution, or students: I prefer to not answer questions concerning evolution, $\mathrm{D}=$ faculty: students should never answer questions concerning evolution, or students: I never answer questions concerning evolution, and $\mathrm{E}=$ do not know enough to say.

Question 6 Your willingness to discuss evolution. Select the statement that describes you best: $\mathrm{A}=\mathrm{I}$ accept evolution and express it openly regardless of other's opinions, $\mathrm{B}=$ no opinion, $\mathrm{C}=\mathrm{I}$ accept evolution but do not discuss it openly to avoid conflicts with friends and family, $\mathrm{D}=\mathrm{I}$ believe in creationism and express it openly regardless of others' opinions, and $\mathrm{E}=\mathrm{I}$ believe in creationism but do not discuss it openly to avoid conflicts with friends and family.

Question 7 Your overall opinion about evolution (question adapted from Miller et al. 2006). Select the statement with which you agree most about "evolution is": $\mathrm{A}=$ definitely true, $\mathrm{B}=$ probably true, $\mathrm{C}=$ definitely false, $\mathrm{D}=$ probably false, and $\mathrm{E}=$ do not know enough to say.

Questions Addressing Views About the Evolutionary Process

Question 8 An acceptable definition of evolution. Indicate if each of the following definitions of evolution is either true or false: $\mathrm{A}=$ gradual process by which the universe changes, it includes the origin of life, its diversification and the synergistic phenomena resulting from the interaction between life and the environment, $\mathrm{B}=$ directional process by which unicellular organisms, like bacteria, turn into multicellular organisms, like sponges, which later turn into fish, amphibians, reptiles, birds, mammals, and ultimately humans, the pinnacle of evolution, $\mathrm{C}=$ gradual process by which monkeys, such as chimpanzees, turn 
into humans, $\mathrm{D}=$ random process by which life originates, changes, and ends accidentally in complex organisms such as humans, and $\mathrm{E}=$ gradual process by which organisms acquire traits during their lifetimes, such as longer necks, larger brains, resistance to parasites, and then pass on these traits to their descendants.

Question 9 Evidence about the evolutionary process. Indicate if each of the following statements about evolution is either true or false: $\mathrm{A}=$ all current living organisms are descendants of common ancestors, which have evolved for thousands, millions, or billions of years, $\mathrm{B}=$ humans are apes, relatives of chimpanzees, bonobos, gorillas and orangutans, $\mathrm{C}=$ the hominid (human lineage) fossil record is so poor that scientists cannot tell with confidence that modern humans evolved from ancestral forms, $\mathrm{D}=$ the origin of the human mind and consciousness cannot be explained by evolution, and $\mathrm{E}=$ the universe, our solar system, and planet Earth are finely tuned to embrace human life.

Questions Addressing Views About Evolution and/or Creation Of Humans and Responders' Religiosity

Question 10 Human evolution with or without creation (question adapted from Berkman et al. 2008). Indicate if each of the following statements about evolution with or without God's intervention is either true or false: $\mathrm{A}=$ humans have evolved over hundreds of thousands of years but God had no part in this process, $\mathrm{B}=$ humans have evolved over hundreds of thousands of years but God guided this process, and $\mathrm{C}=\mathrm{God}$ created humans in their present form within the last 10,000 years.

Question 11 Your religiosity. Indicate if each of the following statements about religiosity is either true or false, select all that apply (question adapted from Pew Global Attitudes Project 2007): A=faith in God is necessary for morality, $\mathrm{B}=$ religion is very important in my life, and $\mathrm{C}=\mathrm{I}$ pray at least once a day.

Religiosity, Understanding-of-Science, and Evolution Indexes

The Pew Global Attitudes Project (2007) has used the three choices of Question 11 (above) to generate a Religiosity
Index (RI), a powerful predictor of religious views worldwide (47 countries), which we applied to our New England faculty and students samples. RI ranges from 0 to 3 (least to most religious position): +1 if responders believe that faith in God is necessary for morality, +1 if religion is very important in their lives, and +1 if they pray daily.

To account for the levels of understanding of science and the evolutionary process, we generated two descriptive indexes (Science Index (SI), Evolution Index (EI)), analogous to RI (above). Thus, we could compare degree of religiosity (RI) with levels of understanding of science (SI) and evolution (EI). Note that scholars in the field of attitudes toward evolution (Bishop and Anderson 1990; Downie and Barron 2000; Trani 2004; Paz-y-Miño C. and Espinosa 2009a, b) have postulated that these three factors might determine an individual's acceptance of evolution. Our SI and EI range from zero to three (lower to higher levels of understanding of science and evolution) and rely on three questions each, which were selected from a pool of five questions about science and ten about evolution (all part of the online surveys); the suitable questions for each index showed variability between the responses by faculty versus students and were, therefore, informative to discriminate between both groups: SI +1 if responders rejected the idea that scientific theories are based on opinions by scientists, +1 if they disagreed with the notion that scientific arguments are as valid and respectable as their nonscientific counterparts, and +1 if they rejected the statement that crime-scene and accident-scene investigators use a different type of scientific method to investigate a crime or an accident; EI +1 if responders rejected the idea that organisms acquire beneficial traits during their lifetimes and then pass on these traits to their descendants, +1 if they disagreed with the notion that during evolution monkeys such as chimpanzees can turn into humans, and +1 if they rejected the statement that the origin of the human mind and consciousness cannot be explained by evolution.

\section{Statistical Analyses}

For the five choice questions (1-7), we compared New England faculty (Fac) versus college students from three types of academic institutions (Pub, Priv, or Rel) and analyzed separately the data generated in each of the questions (i.e., Questions 1, 2, 3, 4, 5, 6, or 7; choices A, B, $\mathrm{C}, \mathrm{D}$, or $\mathrm{E}$ ). Data from each question were organized in $4 \times$ 5 contingency tables, for example, Fac, Pub, Priv, Rel $\times$ A, $\mathrm{B}, \mathrm{C}, \mathrm{D}$, or E (Chi-square tests, null hypotheses rejected at $P \leq 0.05$ ). Because Questions $1,3,4,5,6$, or 7 had none or very few responders $(<5 \%$; note that Chi-square analyses are inaccurate when over $20 \%$ of the expected values are less than five; Sieger and Castellan 1988) in one, two, or 
three of the choices (E or DE or CDE), we eliminated such choices and created $4 \times 2,4 \times 2,4 \times 2,4 \times 2,4 \times 3$, and $4 \times 2$ contingency tables for the remaining groups in each question, respectively (Chi-square tests, null hypotheses rejected at $P \leq 0.05)$. In Question 10 , we analyzed the choices (A, B, or C) as function of the students' institutional affiliation (Pub, Priv, and Rel). Because choice $\mathrm{C}$ had very few responders, we eliminated it (rationale above) and created a $2 \times 3$ contingency table $\mathrm{A}, \mathrm{B} \times \mathrm{Pub}$, Priv, or Rel (Chi-square tests, null hypotheses rejected at $P \leq 0.05$ ). For the true/false questions (Questions 8-9 and 11 , we organized the data corresponding to each subcomponent of the question (Questions 8-9: subcomponents A, B, C, D, and E; Question 11: subcomponents A, B, and C) in separate $2 \times 4$ or $2 \times 3$ contingency tables per each of the five or three subcomponents per question, respectively. For example, Questions 8, subcomponent A: True, False $\times$ Fac, Pub, Priv, or Rel, Question 9, subcomponent A: True, False $\times$ Fac, Pub, or Priv, and Question 11, subcomponent A: True, False $\mathrm{x}$ Fac, Pub, or Priv, (Chi-square tests, null hypotheses rejected at $P \leq 0.05$ ). Note that for Questions 9 and 11 we could not sample students from the religious institution, thus we only compared faculty versus students from the public and private institutions; for Question 10, we sampled only the students (Pub, Priv, or Rel) and compared their perspectives to data from the literature, particularly surveys of high school teachers (Berkman et al. 2008), and extrapolated such comparisons to our analysis (see "Discussion") of patterns of acceptance of evolution by faculty. Pair-wise comparisons between relevant groups in all questions were analyzed with sign test two-tail, null hypotheses rejected at $P \leq 0.05$. Although we instructed participants to not skip questions, they could do it freely (Human Subjects/Institutional Review Boards' policies, above); therefore, the total number of faculty or student responders per question varied, as reported in the figure captions (below): Fac mean=230, $r=216-244$; students Pub mean $=124, r=113-161$, Priv mean $=260, r=180-298$, and Rel mean $=174, r=165-185$. The RI, SI, and EI (above) are descriptive values which range from zero to three each; we generated them as such and discussed them in the context of factors that might determine an individual's acceptance of evolution.

\section{Results}

Survey Response Rates

Faculty Two hundred and forty-four (24.6\%) of the 992 faculty contacted to participate in the study (biologists, 495 : $\mathrm{F}=19.5 \%, \mathrm{M}=30.4 \%$, nonbiologists in ca. 40 disciplines 497: $\mathrm{F}=24.9 \%, \mathrm{M}=25.2 \%$ ) completed the survey (Table 1), a response rate comparable to analogous email/online studies $(24 \%$, The Pew Research Center for the People \& the Press 2009). The average number of faculty contacted per state was $165(r=142-215)$ and the average percent of responders per state was $25(r=23.0-27.9)$. Of all responders $(n=244), 36.9 \%$ were females and $63.1 \%$ were males (Table 1).

Students Response rate by students varied among institutions: Pub, 161 (2.0\% of 7,982 contacted); Priv, 298 (7.8\% of 3,806 contacted); and Rel, 185 ( $4.7 \%$ of 3,910 contacted) (Table 2); these values were consistent with previous online sampling of these institutions where the demographic profile of participants in the surveys resembled closely the institutional profiles (Paz-y-Miño C. and Espinosa 2009a, b). Of all responders $(n=644), \approx 60 \%$ were females and $\approx 40 \%$ were males (means Pub+Priv+Rel; Table 2).

Views About Evolution, Creationism, and ID

Evolution, Creationism and Intelligent Design in the Science Class Faculty and students differed in their views about the teaching of evolution (Fig. 1; Chi-square $=27.072$; $d f=3 ; P \leq 0.001): 96.3 \%$ of the faculty versus $72 \%$ of the students (mean Pub+Priv+Rel) considered that evolution should be taught in science classes as an explanation about

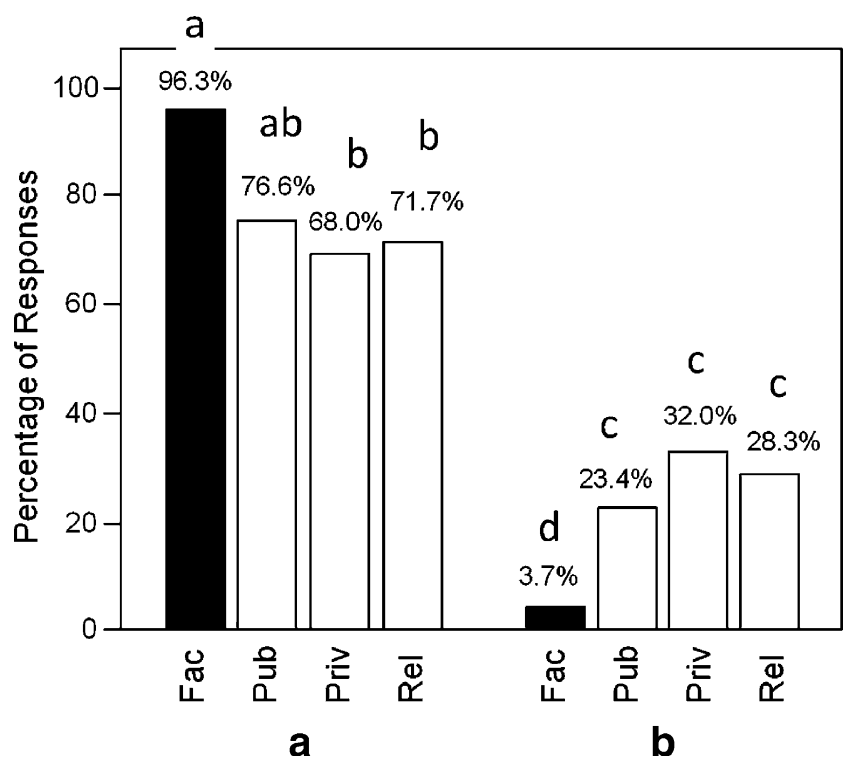

Fig. 1 Percentage of New England faculty (Fac, black bars) versus college students (white bars) from public secular $(P u b)$, private secular (Priv), and religious (Rel) institutions who consider one of the following explanations about the origin and development of life on Earth should be taught in science classes: $A$ evolution and $B$ equal time to evolution, creationism, and intelligent design. Comparisons among groups: Chi-square $=27.072 ; d f=3 ; P \leq 0.001$; lowercase letters indicate sign test two-tail pair-wise comparisons, $P \leq 0.05$. Fac, $n=$ 241; Pub, $n=120$; Priv, $n=266$; and Rel, $n=173$ 
the origin and development of life on Earth; in contrast, $3.7 \%$ of the faculty versus $28 \%$ of the students (mean Pub+ Priv + Rel) favored equal time to evolution, creationism and intelligent design. Support for the exclusive teaching of evolution by faculty versus students from the private $(68.0 \%)$ and religious $(71.7 \%)$ institutions was significantly different (sign test two-tail pair-wise comparison, $P \leq 0.05$ ), however, the level of support to evolution by the students from the public secular institution $(76.6 \%)$ was statistically similar to that of the faculty (sign test two-tail pair-wise comparison, $P=0.17$ ). Although faculty's support for the "equal time" option was negligible (3.7\%), at least one in five (Pub) to one in three students (Priv and Rel) favored it (Fig. 1).

Intelligent Design Faculty had clearly defined opinions about ID, but the students' perception of ID varied (Fig. 2; Chi-square $=63.899 ; d f=12 ; P \leq 0.001): 46.7 / 45.5 \%$ of the faculty versus $22 / 30 \%$ of the students (means Pub+Priv + Rel) perceived ID as either not scientific and proposed to counter evolution based on false claims or as religious doctrine consistent with creationism, respectively. Only the students from the public institution $(\mathrm{Pub}=37.6 \%)$ were statistically similar to the faculty in considering ID a religious doctrine (sign test two-tail pair-wise comparison, $P=0.43$ ). A negligible percent of faculty in comparison to a significant percent of students (means Pub+Priv + Rel) had either no opinion about ID (2.5\% faculty versus $18 \%$ students), considered ID a scientific alternative to evolution and of equal scientific validity among scientists $(2.5 \%$ faculty versus ten percent students), or thought of ID as a scientific theory about the origin of life on Earth $(2.8 \%$ faculty versus $19 \%$ students, sign test two-tail pair-wise comparisons, $P \leq 0.05$; Fig. 2).

Evolution and Responders' Reaction to it Faculty and students differed in their position about evolution (Fig. 3; Chi-square $=31.615 ; d f=3 ; P \leq 0.001): 96.6 \%$ of the faculty versus $79 \%$ of the students (mean Pub + Priv + Rel) thought that hearing about evolution makes them appreciate the factual explanation about the origin of life on Earth and its place in the universe; in contrast, $3.4 \%$ of the faculty versus $23 \%$ of the students (mean Pub+Priv+Rel) considered that hearing about evolution makes no difference because evolution and creationism are in harmony. Both the students from the public ( $\mathrm{Pub}=87.2 \%$ ) and private (Priv $=81.5 \%$ ) institutions were statistically similar to the faculty in preferring solely evolutionary explanations in science classes about the origin of life (sign test two-tail pair-wise comparisons, $P \geq 0.05$; Fig. 3 ). Note that the students from the public, private and religious institutions are about four, six and ten times more likely than the faculty to think that evolution and creationism are in harmony, respectively (sign test two-tail pair-wise comparisons, $P \leq 0.05$; Fig. 3).

Position About the Teaching of Human Evolution Faculty and students agreed on their views about the teaching of human evolution (Fig. 4; Chi-square $=6.802 ; d f=3 ; P=$ 0.078): $98.8 \%$ of the faculty versus $95 \%$ of the students

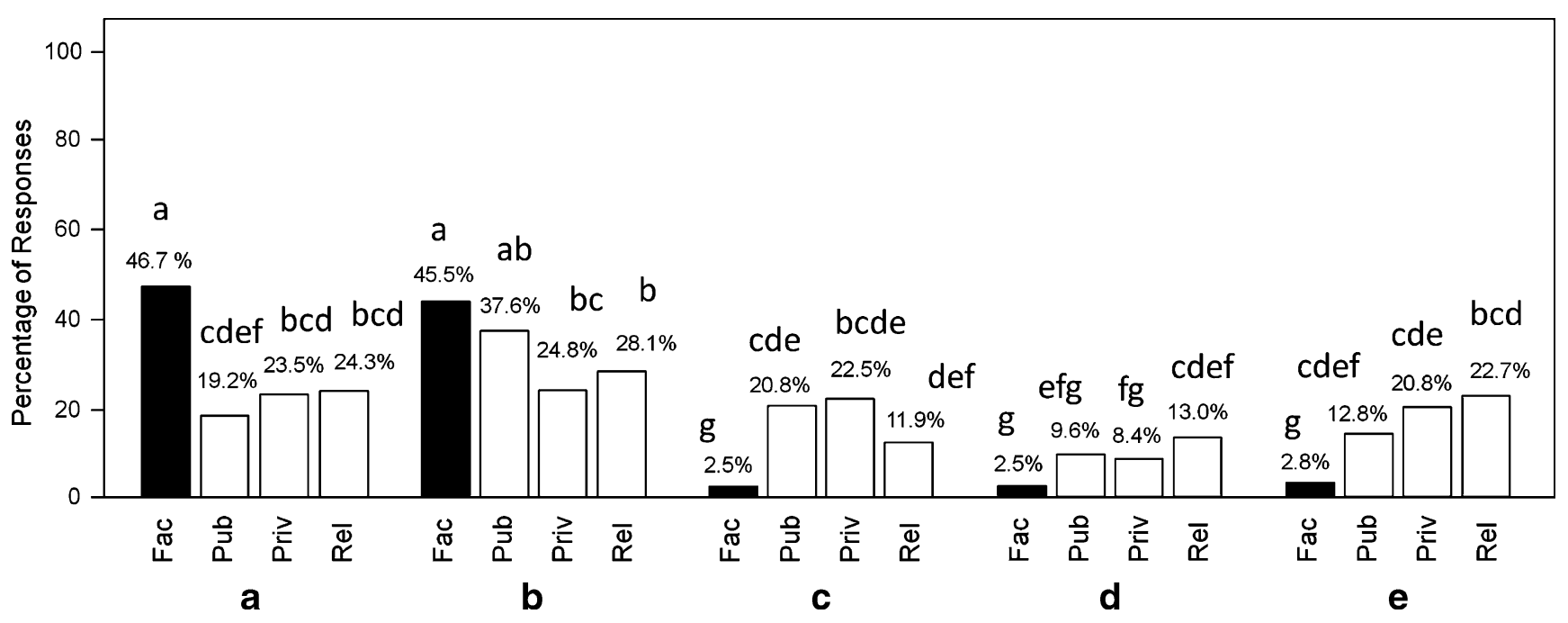

Fig. 2 Percentage of New England faculty (Fac, black bars) versus college students (white bars) from public secular $(P u b)$, private secular (Priv), and religious (Rel) institutions who consider one of the following statements to be consistent with intelligent design (ID): $A$ ID is not scientific but has been proposed to counter evolution based on false claims; $B$ ID is religious doctrine consistent with creationism;
$C$ no opinion; $D$ ID is a scientific alternative to evolution and of equal scientific validity among scientists; $E$ ID is a scientific theory about the origin and evolution of life on Earth. Comparisons among groups: Chi-square $=63.899 ; d f=12 ; P \leq 0.001$; lowercase letters indicate sign test two-tail pair-wise comparisons, $P \leq 0.05$. Fac, $n=244$; Pub, $n=$ 125 1; Priv, $n=298$; and Rel, $n=185$ 
a

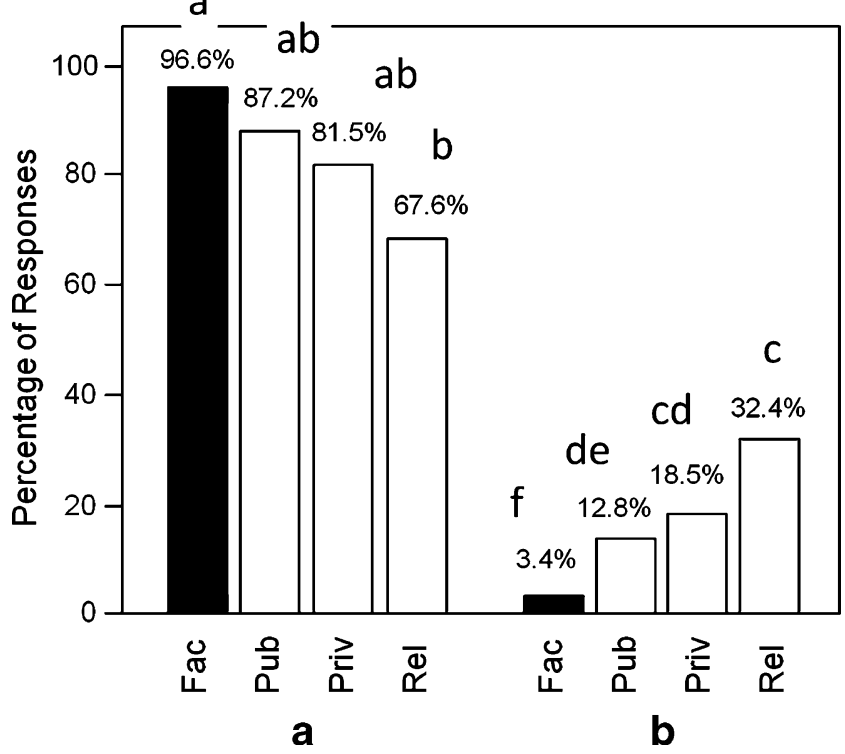

Fig. 3 Percentage of New England faculty (Fac, black bars) versus college students (white bars) from public secular (Pub), private secular (Priv), and religious (Rel) institutions who think one of the following statements fits best their position concerning evolution: $A$ hearing about evolution makes me appreciate the factual explanation about the origin of life on Earth and its place in the universe; $B$ hearing about evolution makes no difference to me because evolution and creationism are in harmony. Comparisons among groups: Chisquare $=31.615, d f=3, P \leq 0.001$; lowercase letters indicate sign test two-tail pair-wise comparisons, $P \leq 0.05$. Fac, $n=236$; Pub, $n=117$; Priv, $n=259$; and Rel, $n=176$

(mean Pub + Priv + Rel) preferred science courses where evolution is discussed comprehensively and humans are part of it, and only $1.2 \%$ of the faculty versus five percent of the students (mean Pub+Priv+Rel) preferred evolution discussions about plants and animals but not humans. In each case (i.e., science courses including or excluding human evolution) faculty versus student responses were statistically similar (sign test two-tail pair-wise comparisons, $P \geq 0.05$; Fig. 4).

Evolution in Science Exams Faculty and students shared opinions about the inclusion of evolution in science exams (Fig. 5; Chi-square $=1.204 ; d f=3 ; P=0.752$ ): about $78 \%$ of the combined faculty plus student responders (mean $\mathrm{Fac}+\mathrm{Pub}+$ Priv + Rel) had no problem with either instructors including questions concerning evolution in exams or answering questions concerning evolution in exams, respectively, and 22\% (mean $\mathrm{Fac}+\mathrm{Pub}+$ Priv + Rel) considered that exams should always include some questions concerning evolution. In each case (i.e., optional or required inclusion of questions about evolution in exams) faculty versus student responses were statistically similar (sign test two-tail pair-wise comparisons, $P \geq 0.05$; Fig. 5).

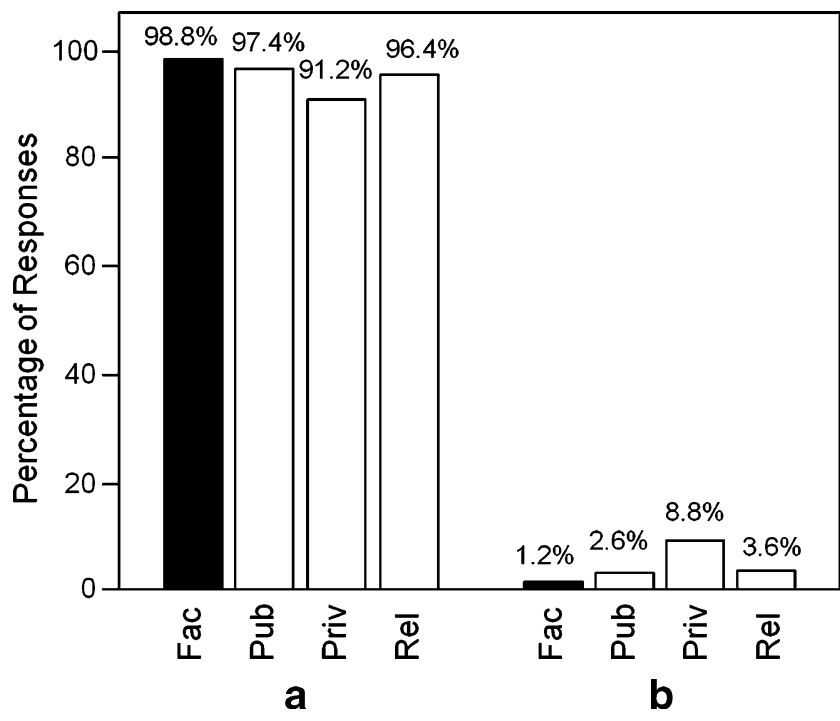

Fig. 4 Percentage of New England faculty (Fac, black bars) versus college students (white bars) from public secular $(P u b)$, private secular (Priv), and religious ( $R e l)$ institutions who agree with one of the following statements concerning their own education: $A$ I prefer science courses where evolution is discussed comprehensively and humans are part of it; $B$ I prefer science courses where plant and animal evolution is discussed but not human evolution. Comparisons among groups: Chi-square $=6.802 ; d f=3 ; P=0.078$. Fac, $n=242$; Pub, $n=117$; Priv, $n=261$; and Rel, $n=169$

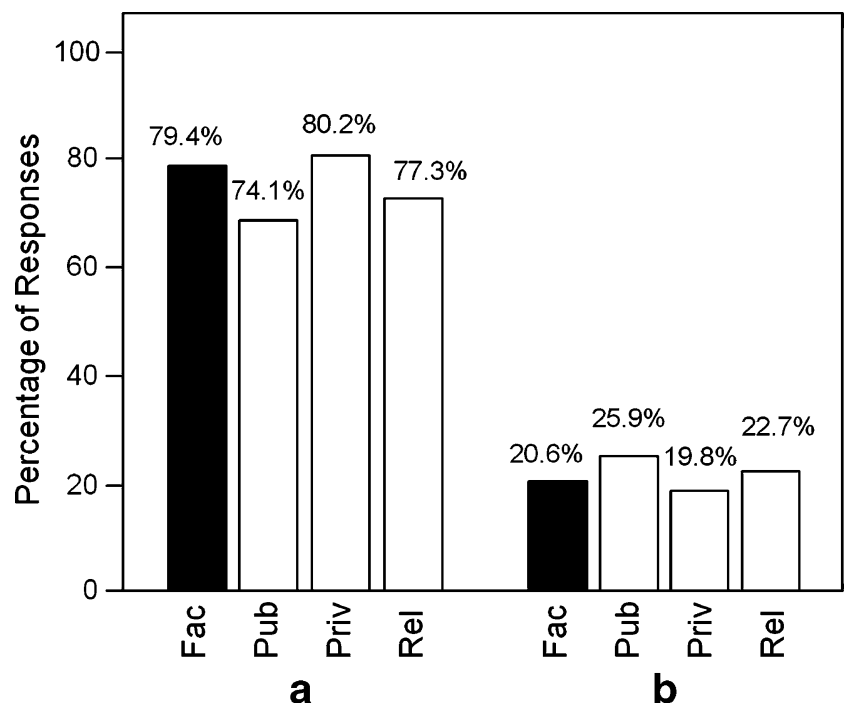

Fig. 5 Percentage of New England faculty (Fac, black bars) versus college students (white bars) from public secular $(P u b)$, private secular (Priv), and religious ( $R e l)$ institutions who agree with one of the following statements concerning evolution in science exams: $A$ Fac: instructors should have no problem giving exams with questions concerning evolution, or students: I have no problem answering questions concerning evolution; $B$ science exams should always include some questions concerning evolution. Comparisons among groups: Chi-square $=1.204 ; d f=3 ; P=0.752$. Fac, $n=238$; Pub, $n=116$; Priv, $n=258$; and Rel, $n=172$ 


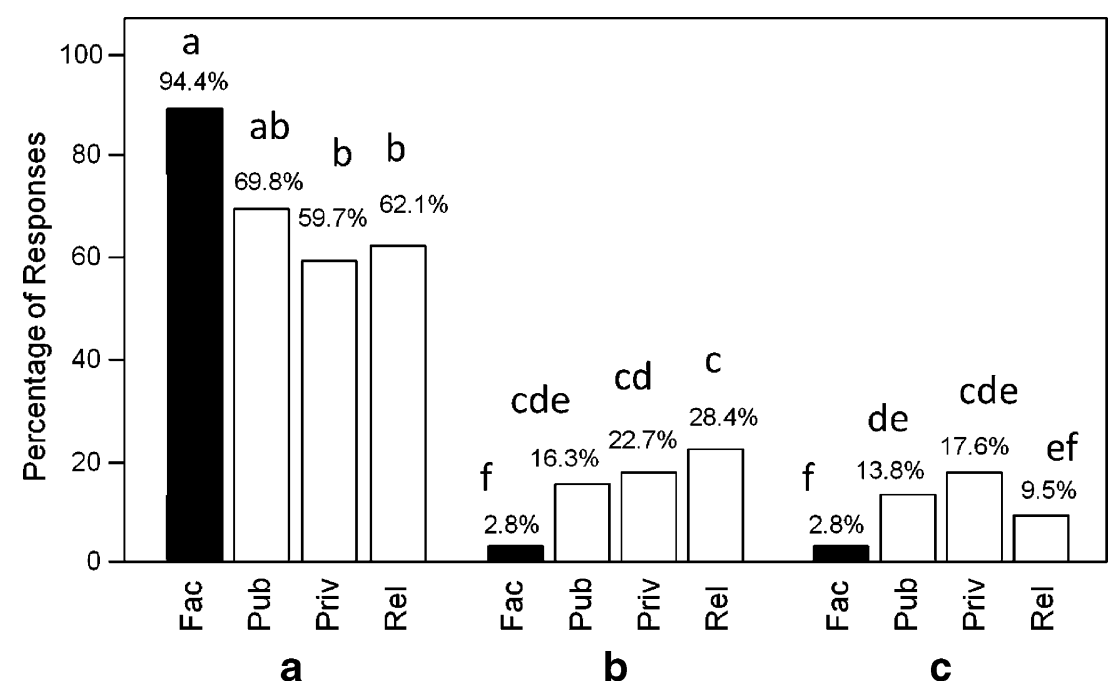

Fig. 6 Percentage of New England faculty (Fac, black bars) versus college students (white bars) from public secular (Pub), private secular (Priv), and religious ( $R e l)$ institutions who believe one of the following statements describes them best: $A \mathrm{I}$ accept evolution and express it openly regardless of others' opinions; $B$ no opinion; and $C$ I

Willingness to Discuss Evolution Faculty and students differed in their willingness to offer opinions about evolution (Fig. 6; Chi-square $=41.326 ; d f=6 ; P \leq 0.001$ ): $94.4 \%$ of the faculty versus $64 \%$ of the students (mean Pub+Priv+Rel) indicated they accept evolution and express it openly regardless of others' opinions, $2.8 \%$ of the faculty versus $22 \%$ of the students (mean Pub+Priv + Rel) preferred not to comment on this issue, and $2.8 \%$ of the faculty versus $14 \%$ of the students (mean Pub+Priv + Rel) admitted they accept evolution but do not discuss it openly to avoid conflicts with friends and family. Only the students from the public institution ( $\mathrm{Pub}=69.8 \%$ ) were statistically similar to the faculty in accepting evolution openly (sign test two-tail pair-wise comparison $P=0.072$ ).

Overall Opinion About Evolution Faculty and students differed in their overall opinion about evolution (Fig. 7; Chi-square $=21.788 ; d f=3 ; P \leq 0.001): 81.9 \%$ of the faculty versus $58 \%$ of the students (mean Pub+Priv + Rel) thought that evolution is definitely true, and $18.1 \%$ of the faculty versus $42 \%$ of the students (mean Pub+Priv + Rel) thought that evolution is probably true. Only the students from the public institution $(\mathrm{Pub}=62.8 \%)$ were statistically similar to the faculty in thinking that evolution is definitely true (sign test two-tail pair-wise comparison, $P=0.134$ ).

Views About the Evolutionary Process

An Acceptable Definition of Evolution There was noticeable variation in the views of faculty versus students about alternative definitions of evolution (Fig. 8): $80 \%$ of the accept evolution but do not discuss it openly to avoid conflicts with friends and family. Comparisons among groups: Chi-square $=41.326$; $d f=6 ; P \leq 0.001$; lowercase letters indicate sign test two-tail pair-wise comparisons, $P \leq 0.05$. Fac, $n=216$; Pub, $n=116$; Priv, $n=273$; and Rel, $n=169$

faculty and $84 \%$ of the students (mean Pub+Priv+Rel) considered definition A of evolution as true: gradual process by which the universe changes, it includes the origin of life, its diversification and the synergistic phenomena resulting from the interaction between life and the environment; faculty and student responses were statistically similar (within group comparisons, Chi-square $=3.827 ; d f=3 ; P=$

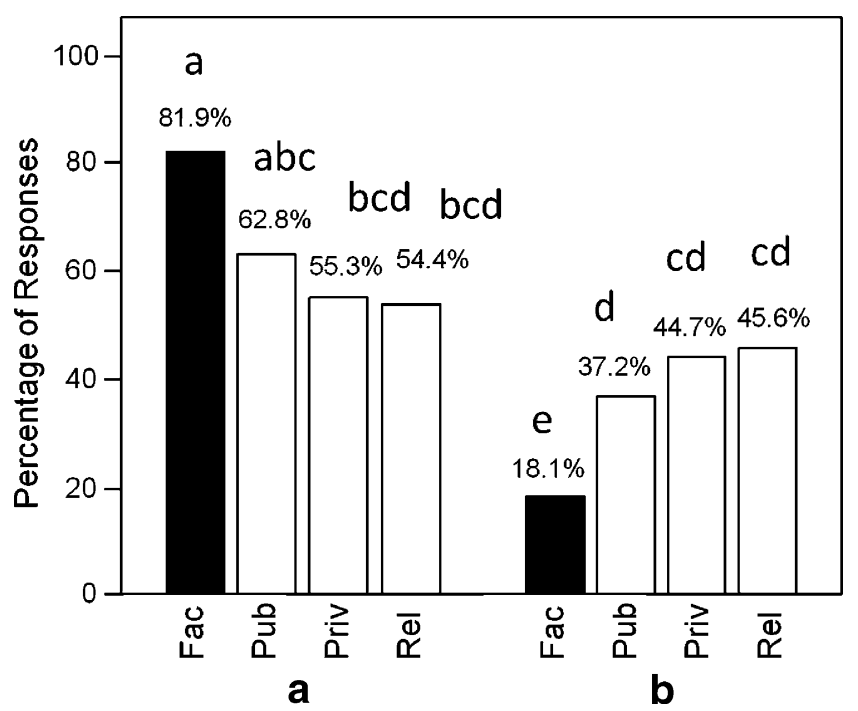

Fig. 7 Percentage of New England faculty (Fac, black bars) versus college students (white bars) from public secular (Pub), private secular (Priv), and religious (Rel) institutions who think evolution is: $A$ definitely true and $B$ probably true. Comparisons among groups: Chi-square $=21.788 ; d f=3 ; P \leq 0.001 ;$ lowercase letters indicate sign test two-tail pair-wise comparisons, $P \leq 0.05$. Fac, $n=216$; Pub, $n=113$; Priv, $n=253$; and Rel, $n=171$ 


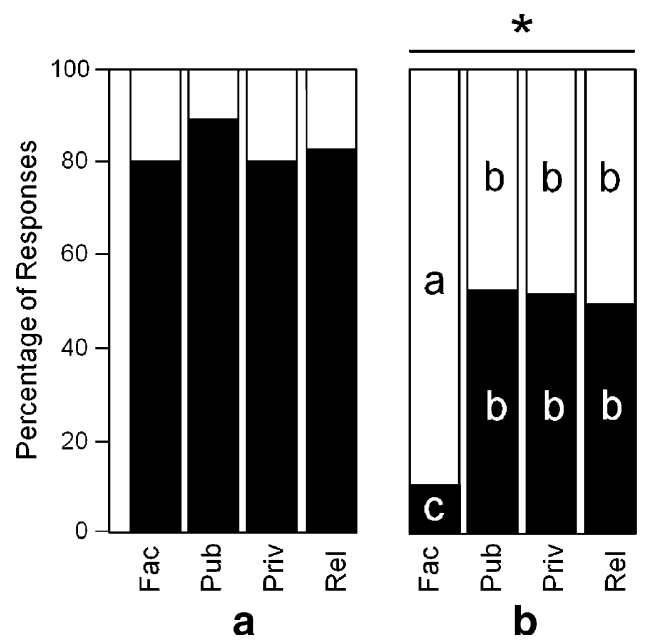

Fig. 8 Percentage of New England faculty $(\mathrm{Fac})$ versus college students from public secular $(P u b)$, private secular (Priv), and religious $(R e l)$ institutions who consider the following definitions of evolution to be either true (black bars) or false (white bars): $A$ gradual process by which the universe changes, it includes the origin of life, its diversification and the synergistic phenomena resulting from the interaction between life and the environment; $B$ directional process by which unicellular organisms, like bacteria, turn into multicellular organisms, like sponges, which later turn into fish, amphibians, reptiles, birds, mammals, and ultimately humans, the pinnacle of evolution; $C$ gradual process by which monkeys such as chimpanzees,

0.281); note that definition A was the most comprehensive included in the survey. Eleven percent of the faculty versus $50 \%$ of the students (mean Pub+Priv + Rel) considered definition $\mathrm{B}$ of evolution as true: directional process by which unicellular organisms, like bacteria, turn into multicellular organisms, like sponges, which later turn into fish, amphibians, reptiles, birds, mammals and ultimately humans, the pinnacle of evolution (within group comparisons, Chi-square $=48.511 ; d f=3 ; P \leq 0.001)$; the faculty correctly rejected this definition $(89 \%$ considered it false, sign test two-tail pair-wise comparison $P \leq 0.05$; Fig. 8), while the students' true/false responses (Pub, Priv, and Rel) were similar to each other and to chance (sign test two-tail pair-wise comparisons, $P \geq 0.05$; Fig. 8); note that definition B implies purpose in evolution and goal toward "humanity." Six percent of the faculty versus $26 \%$ of the students (mean $\mathrm{Pub}+$ Priv + Rel) considered definition $\mathrm{C}$ of evolution as true: gradual process by which monkeys, such as chimpanzees, turn into humans (within group comparisons, Chi-square= $23.455 ; d f=3 ; P \leq 0.001)$; the faculty correctly rejected this definition $(94 \%$ considered it false, sign test two-tail pairwise comparison $P \leq 0.05$; Fig. 8 ) while the students' true/ false responses (Pub, Priv, and Rel) were similar to each other and to chance (sign test two-tail pair-wise comparisons, $P \geq 0.05$; Fig. 8); note that definition $\mathrm{C}$ asserts that chimpanzees are "monkeys" and that humans evolved from them. Thirty percent of the faculty and $29 \%$ of the students (mean Pub+Priv + Rel) considered definition D of evolution
$*$
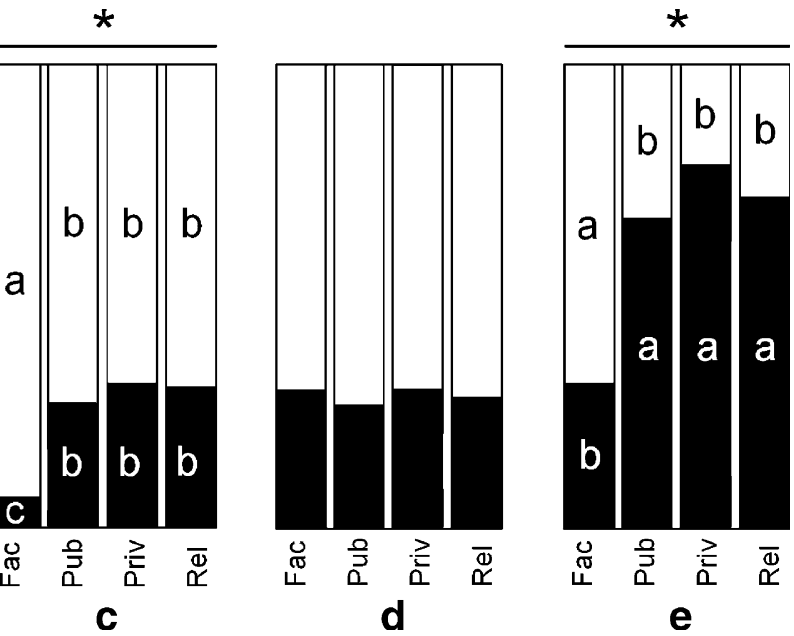

turn into humans; $D$ random process by which life originates, changes, and ends accidentally in complex organisms such as humans; and $E$ gradual process by which organisms acquire traits during their lifetimes, such as longer necks, larger brains, resistance to parasites, and then pass on these traits to their descendants. Comparisons within groups (asterisks indicate significance): $A$, Chi-square $=3.827 ; d f=3$; $P=0.281$. $B$, Chi-square $=48.511 ; d f=3 ; P \leq 0.001$. $C$, Chi-square $=$ 23.455; $d f=3 ; P \leq 0.001$. $D$, Chi-square $=0.291 ; d f=3 ; P=0.962 ; E$, Chi-square $=50.003 ; d f=3 ; P \leq 0.001$. Lowercase letters indicate sign test two-tail pair-wise comparisons within groups, $P \leq 0.05$. Fac, $n=$ 221; Pub, $n=161$; Priv, $n=223$; Rel, $n=185$

as true: random process by which life originates, changes, and ends accidentally in complex organisms such as humans; both faculty and students correctly rejected this definition ( $70 \%$ and $71 \%$, respectively) and their responses were statistically similar (within group comparisons, Chisquare $=0.291 ; d f=3 ; P=0.962)$; note that definition $\mathrm{D}$ implies that evolution is random and accidental. Thirty-one percent of the faculty versus $72 \%$ of the students (mean Pub + Priv+Rel) considered definition E of evolution as true: gradual process by which organisms acquire traits during their lifetimes, such as longer necks, larger brains, resistance to parasites, and then pass on these traits to their descendants (within group comparisons, Chi-square $=$ $50.003 ; d f=3 ; P \leq 0.001) ; 69 \%$ of the faculty versus $28 \%$ of the students (mean Pub+Priv+Rel) correctly rejected this Lamarckian definition, note that faculty and students true/ false responses were both contrasting (Fac 31/69\% versus students $72 / 28 \%$ means Pub+Priv + Rel) and statistically different (sign test two-tail pair-wise comparisons, $P \leq 0.05$; Fig. 8).

Evidence About the Evolutionary Process Faculty and students varied in their understanding of how evolution works (Fig. 9); because we could not assess this topic among students from the religious institution (rationale above), here we compare faculty only with students from the public and private institutions: $94 \%$ of the faculty and $89 \%$ of the students (mean Pub+Priv) correctly considered 


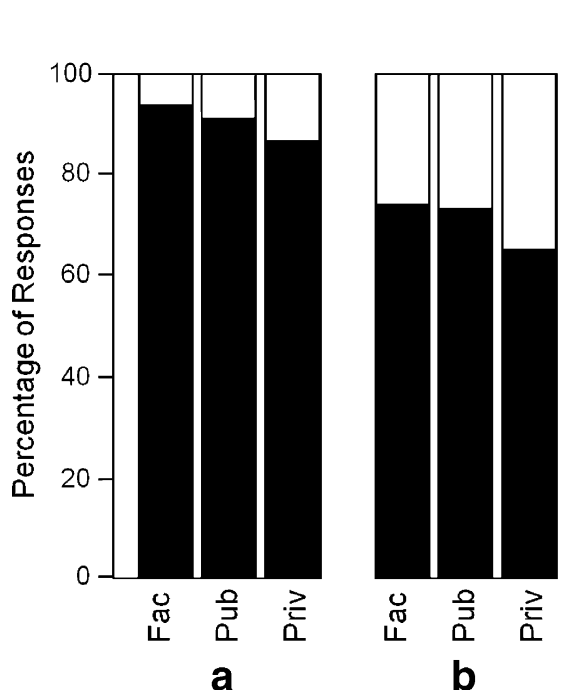

Fig. 9 Percentage of New England faculty ( $F a c$ ) versus college students from public secular $(P u b)$, and private secular (Priv) institutions who consider the following statements about evolution to be either true (black bars) or false (white bars): $A$ all current living organisms are descendants of common ancestors, which have evolved for thousands, millions, or billions of years; $B$ humans are apes, relatives of chimpanzees, bonobos, gorillas, and orangutans; $C$ the hominid (human lineage) fossil record is so poor that scientists cannot tell with confidence that modern humans evolved from ancestral

statement A as true: all current living organisms are descendants of common ancestors, which have evolved for thousands, millions, or billions of years; faculty and student responses were statistically similar (within group comparisons, Chi-square=4.097; $d f=2 ; P=0.129)$. Seventy-four percent of the faculty versus $70 \%$ of the students (mean Pub + Priv) correctly considered statement B as true: humans are apes, relatives of chimpanzees, bonobos, gorillas, and orangutans; faculty and student responses were statistically similar (within group comparisons, Chisquare $=2.623 ; d f=2 ; P=0.269)$. Four percent of the faculty versus $20 \%$ of the students (mean Pub+Priv) considered statement $\mathrm{C}$ as true: the hominid (human lineage) fossil record is so poor that scientists cannot tell with confidence that modern humans evolved from ancestral forms (within group comparison Chi-square $=13.411 ; d f=2 ; P=0.001$ ); significantly less faculty than students thought that this statement was true (sign test two-tail pair-wise comparisons, $P \leq 0.05$; Fig. 9); note that both $96 \%$ of the faculty and $80 \%$ of the students (mean Pub+Priv) correctly rejected this statement, and these responses were statistically similar (sign test two-tail pair-wise comparisons, $P \geq 0.05$; Fig. 9). Fifteen percent of the faculty versus $34 \%$ of the students (mean Pub+Priv) considered statement D as true: the origin of the human mind and consciousness cannot be explained by evolution (within group comparison Chi-square $=14.533 ; d f=2 ; P \leq 0.001$ ); faculty responses were statistically similar to those by the students from the

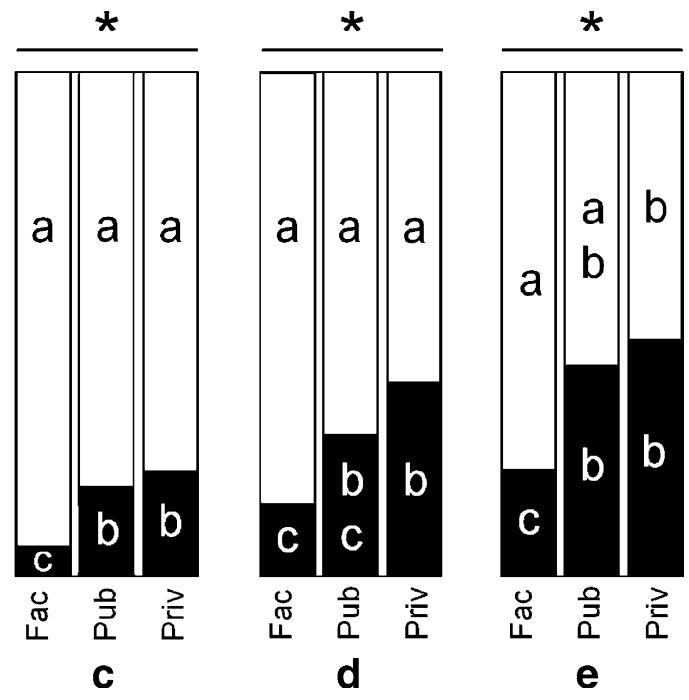

forms; $D$ the origin of the human mind and consciousness cannot be explained by evolution; and $E$ the universe, our solar system, and planet Earth are finely tuned to embrace human life. Comparisons within groups (asterisks indicate significance): $A$, Chi-square $=4.097$; $d f=2 ; P=0.129 . B$, Chi-square $=2.623 ; d f=2 ; P=0.269 . C$, Chi-square $=13.411 ; d f=2 ; P=0.001 . D$, Chi-square $=14.533 ; d f=2 ; P \leq 0.001 . E$, Chi-square $=15.191 ; d f=2 ; P \leq 0.001$. Lowercase letters indicate sign test two-tail pair-wise comparisons within groups, $P \leq 0.05$. Fac, $n=$ 221; Pub, $n=124$; and Priv, $n=295$

public institution (sign test two-tail pair-wise comparisons, $P \geq 0.05$; Fig. 9) but differed from those by the students from the private institution (sign test two-tail pair-wise comparisons, $P \leq 0.05$; Fig. 9); note that both $85 \%$ of the faculty and $66 \%$ of the students (mean Pub+Priv) correctly rejected this statement and that these responses were statistically similar (sign test two-tail pair-wise comparisons, $P \geq 0.05$; Fig. 9). Twenty-one percent of the faculty versus $44 \%$ of the students (mean Pub+Priv) considered statement $\mathrm{E}$ as true: the universe, our solar system and planet Earth are finely tuned to embrace human life (within group comparisons, Chi-square $=15.191 ; d f=2 ; P \leq 0.001$ ); significantly less faculty than students thought that this statement was true (sign test two-tail pair-wise comparisons, $P \leq 0.05$; Fig. 9); both $79 \%$ of the faculty and $56 \%$ of the students (mean Pub+Priv) correctly rejected this statement; note that faculty responses were statistically similar to those by the students from the public institution (sign test two-tail pairwise comparisons, $P \geq 0.05$; Fig. 9) but differed from those by the students from the private institution (sign test two-tail pair-wise comparisons, $P \leq 0.05$; Fig. 9)

Views About Evolution and/or Creation of Humans and Responders' Religiosity

Human Evolution With or Without Creation Because we could not assess this topic among the faculty (the surveys 
were not identical in this topic), we show here only the students' perspectives, which we discuss (see discussion below) in the context of comparisons with relevant literature. Students from public, private, and religious institutions varied in their views about the evolution or creation of humans (Fig. 10; Chi-square $=35.006 ; d f=2 ; P \leq 0.001$ ): $65 \%$ of the students from public and private institutions (mean Pub+ Priv) versus $28.5 \%$ of the students from the religious institution thought that humans have evolved over hundreds of thousands of years but God had no part in this process; and $35 \%$ of the students from public and private institutions (mean Pub+Priv) versus $71.5 \%$ of the students from the religious institution believed that humans have evolved over hundreds of thousands of years but God guided this process. Opinions by the students from the secular public and private institutions were statistically similar (sign test two-tail pairwise comparisons, $P \geq 0.05$ ) but differed from the views by the students from the religious institution (sign test two-tail pair-wise comparisons, $P \leq 0.05$ ).

Your Religiosity Faculty and students varied in their religiosity (Fig. 11); because we could not assess this topic among students from the religious institution (rationale above), here we compare faculty only with students from the public and private institutions: $5 \%$ of the faculty and $24 \%$ of the students (mean Pub+Priv) considered statement A as true: faith in God is necessary for morality (within group comparisons, Chi-square $=17.096 ; d f=2 ; P \leq 0.001$ ); significantly less faculty than students thought that this statement was true (sign test two-tail pair-wise comparisons, $P \leq 0.05$;

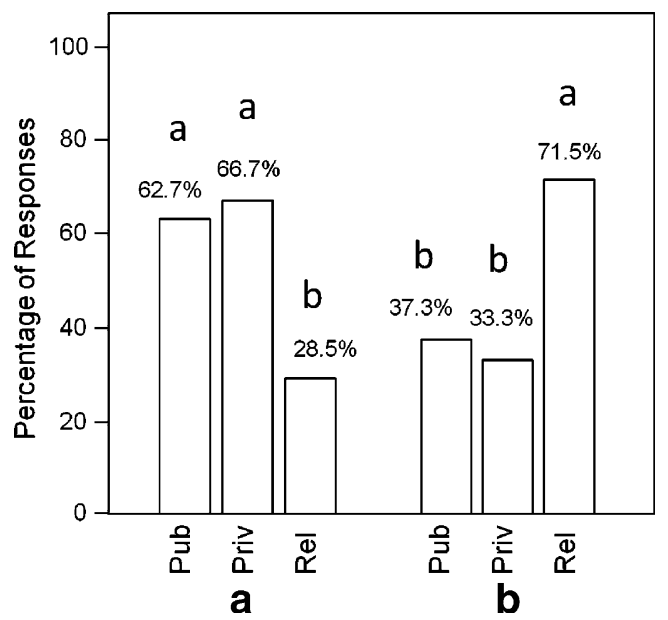

Fig. 10 Percentage of New England college students from public secular $(P u b)$, private secular (Priv), and private religious (Rel) institutions who agree with the following statements: $A$ humans have evolved over hundreds of thousands of years but God had no part in this process and $B$ humans have evolved over hundreds of thousands of years but God guided this process. Comparisons between groups: Chi-square $=35.006 ; d f=2 ; P \leq 0.001$; lowercase letters indicate sign test two-tail pair-wise comparisons, $P \leq 0.05$. Pub, $n=126$; Priv, $n=$ 180; Rel, $n=165$

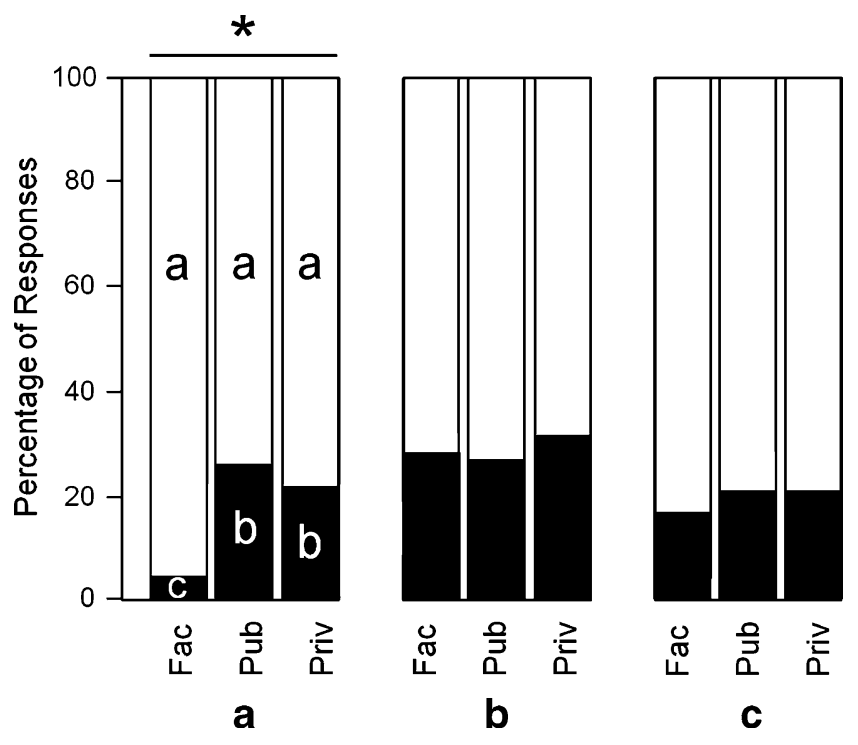

Fig. 11 Percentage of New England faculty $(\mathrm{Fac})$ versus college students from public secular $(P u b)$, and private secular (Priv) institutions who consider the following statements about religiosity to be either true (black bars) or false (white bars): $A$ faith in God is necessary for morality, $B$ religion is very important in my life, and $C$ I pray at least once a day. Comparisons within groups (asterisks indicate significance): $A$, Chi-square $=17.096 ; d f=2 ; P \leq 0.001 . B$, Chi-square $=$ $0.611 ; d f=2 ; P=0.737$. $C$, Chi-square $=0.675 ; d f=2 ; P=0.713$. Lowercase letters indicate sign test two-tail pair-wise comparisons within groups, $P \leq 0.05$. Fac, $n=221$; Pub, $n=125$; and Priv, $n=298$

Fig. 11); $95 \%$ of the faculty and $76 \%$ of the students (mean Pub+Priv) considered this statement as false, and these responses were statistically similar (sign test two-tail pairwise comparisons, $P \geq 0.05$; Fig. 11). Twenty-nine percent of the faculty and $30 \%$ of the students (mean Pub+Priv) considered statement $\mathrm{B}$ as true: religion is very important in my life; faculty and student responses were statistically similar (within group comparisons, Chi-square $=0.611 ; d f=2$; $P=0.737$; Fig. 11 ); note that $71 \%$ of the faculty and $70 \%$ of the students (mean Pub+Priv) thought that this statement was false. Seventeen percent of the faculty and $21 \%$ of the students (mean Pub+Priv) considered statement $\mathrm{C}$ as true: $I$ pray at least once a day; faculty and student responses were statistically similar (within group comparisons, Chi-square $=$ $0.675 ; d f=2 ; P=0.713$; Fig. 11$)$; note that $83 \%$ of the faculty and $79 \%$ of the students (mean Pub+Priv) thought that this statement was false.

Religiosity, Understanding-of-Science, and Evolution Indexes

The levels of RI, SI, and EI were clearly distinctive for faculty and students:

Religiosity Index Fac RI=0.50 ( $n=221)$, Pub RI=0.74 ( $n=$ 123), and Priv RI=0.76 $(n=288)$; note that the disparity 
between faculty and students relied mainly on choice A of Question 11 (faith in God is necessary for morality) since the partial scores of RI for choices B or C (Fig. 11) were similar: Fac partial scores RI choice $\mathrm{A}=0.05$, choice $\mathrm{B}=$ 0.28 , choice $C=0.17$ versus Pub partial scores RI choice $\mathrm{A}=0.26$, choice $\mathrm{B}=0.28$, choice $\mathrm{C}=0.20$ versus Priv partial scores RI choice $\mathrm{A}=0.22$, choice $\mathrm{B}=0.32$, choice $\mathrm{C}=0.22$.

Understanding-of-Science Index Fac SI=2.27 $(n=221)$, Pub SI=1.62 $(n=123)$, and Priv SI=1.58 $(n=288)$; the disparity between faculty and students was evident in each of the partial scores of SI as follows: for statement scientific theories are based on opinions by scientists the partial scores were Fac SI $=0.89$, Pub SI $=0.62$, and Priv SI $=$ 0.63; for statement scientific arguments are as valid and respectable as their nonscientific counterparts the partial scores were Fac $\mathrm{SI}=0.57$, Pub SI=0.33, and Priv $\mathrm{SI}=0.33$; and for statement crime-scene and accident-scene investigators use a different type of scientific method to investigate a crime or an accident the partial scores were Fac SI=0.81, Pub SI=0.67, and Priv SI=0.62.

Understanding-of-Evolution Index Fac $\mathrm{EI}=2.48(n=221)$, Pub EI=1.77 $(n=123)$, and Priv EI=1.54 $(n=288)$; the disparity between faculty and students was evident in each of the partial scores of EI as follows: for statement organisms acquire beneficial traits during their lifetimes and then pass on these traits to their descendants the partial scores were Fac $\mathrm{EI}=0.68$, Pub EI=0.33, and Priv $\mathrm{EI}=0.22$; for statement during evolution monkeys such as chimpanzees can turn into humans the partial scores were Fac EI= 0.95, Pub EI $=0.72$, and Priv EI $=0.70$; and for statement the origin of the human mind and consciousness cannot be explained by evolution the partial scores were $\mathrm{Fac} \mathrm{EI}=0.85$, Pub EI $=0.72$, and Priv EI $=0.62$.

\section{Discussion}

Below, we round up the values when discussing them in the context of generalizations and remarking on the most relevant patterns:

Views About Evolution, Creationism, and ID

The New England faculty versus students views about evolution, creationism and ID differed distinctly: $96 \%$ of the faculty versus $72 \%$ of the students supported the exclusive teaching of evolution in science classes, and only $4 \%$ of the faculty versus $28 \%$ of the students favored equal time to evolution, creationism and intelligent design (Fig. 1); $92 \%$ of the faculty versus $52 \%$ of the students perceived ID as either not scientific and proposed to counter evolution based on false claims or as religious doctrine consistent with creationism (combined values choices A+B, Fig. 2). Only $8 \%$ of the faculty versus $48 \%$ of the students had either no opinion about ID, considered it a scientific alternative to evolution and of equal scientific validity among scientists, or thought of ID as a scientific theory about the origin of life on Earth (combined values choices $\mathrm{C}+\mathrm{D}+\mathrm{E}$; Fig. 2). Although the faculty had clear understanding of ID, the students varied widely in their level of knowledge of ID; only the students from the public institution seemed to be more aware of the nature of ID than their counterparts at the private and religious institutions. We suspect that the particularly strong teaching program in biology and evolution at the public institution (UMassD) might account for this pattern.

Most faculty (97\%) and students from the public (87\%) and private $(82 \%)$ institutions preferred factual explanations about the origin of life on Earth and its place in the universe (choice A, Fig. 3), but students from the religious institution were less supportive of this view $(68 \%)$. Note that students from the public, private and religious institutions were about four, six, and ten times more likely than the faculty (only $3 \%$ ) to think that evolution and creationism are in harmony, respectively (choice B, Fig. 3). Interestingly, $96 \%$ of faculty and students preferred science courses where evolution is discussed comprehensively and humans are part of it (mean combined values choice A, Fig. 4), and $78 \%$ of all responders had no problem with either instructors including questions concerning evolution in exams or answering questions concerning evolution (mean combined values choice A, Fig. 5); in fact, one in every five responders considered that science exams should always include some questions concerning evolution (choice B, Fig. 5).

Most faculty (94\%) indicated they accept evolution and express it openly regardless of others' opinions and only $3 \%$ admitted to accepting it privately (choices $\mathrm{A}$ and $\mathrm{C}$, Fig. 6); in contrast, $64 \%$ of the students accepted evolution openly, $22 \%$ preferred not to comment on this issue, and $14 \%$ admitted to accepting evolution only privately to avoid conflicts with friends and family (mean combined values choices A-C, Fig. 6). Note that $82 \%$ of the faculty and $58 \%$ of the students thought that evolution is definitely true (mean combined values choice A, Fig. 7).

Although in Questions 1, choice A; 2, choices A+B; 3, choice $A ; 6$, choice $A$; and 7 , choice $A$ (above), the faculty versus student highest rate of responses differed by about $30 \%$ (mean of summation highest scores faculty versus students, Figs. 1, 2, 3, 6, and 7), the student responses from the public institution were statistically similar to the faculty in all of these choices (only choice B in Question 2), suggesting more proximity between the views of these two 
groups than between the faculty and the students from the private and religious institutions. Again, the strong teaching program in biology and evolution at the public institution might account for this pattern (above).

\section{Views About the Evolutionary Process}

As we expected, New England faculty showed a better understanding of the evolutionary process than the students; however, both coincided and differed from each other in important ways. For example, $82 \%$ (mean value) of faculty and students agreed with a comprehensive definition of evolution as a gradual process by which the universe changes, [which] includes the origin of life, its diversification and the synergistic phenomena resulting from the interaction between life and the environment, and 70\% (mean value) correctly rejected the definition that evolution is a random process by which life originates, changes, and ends accidentally in complex organisms such as humans (choices A and D, Fig. 8). Faculty correctly rejected (89\%) the notion of "purpose" and "goal toward humanity" in evolution (choice B, Fig. 8), and also the misconception that humans have evolved from chimpanzees (rejection 94\%, choice C, Fig. 8) or the possibility of Lamarckian inheritance of acquired traits (rejection only $69 \%$, choice E, Fig. 8). In contrast, the students were not sure if evolution has a purpose or goal, $26 \%$ believed that humans come from "monkeys such as chimpanzees," and $72 \%$ were Lamarckian (choices B, C, and E, respectively, Fig. 8). Surprisingly, $30 \%$ of the faculty were Lamarckian themselves (choice E, Fig. 8).

The level of understanding of how evolution works varied clearly between faculty and students. Both agreed that evolution relies on common ancestry $(92 \%$, mean choice A, Fig. 9) and that humans are apes (72\%, mean choice B, Fig. 9); however, one in every four faculty and one in every three students did not know, or accept, that humans are close relatives to chimpanzees, bonobos, gorillas, and orangutans (choice B, Fig. 9). Most faculty (96\%) but only $80 \%$ of the students knew that the hominid fossil record is rich enough for scientists to conclude that humans have evolved from ancestral forms, and $15 \%$ of the faculty versus $34 \%$ of the students (mean) still believed, incorrectly, that the origin of the human mind cannot be explained by evolution (choices $\mathrm{C}$ and D, Fig. 9); indeed, one in every five faculty and almost half of the students (mean) thought, erroneously, that the universe, our solar system and planet Earth are finely tuned to embrace human life (choice E, Fig. 9). The latter is a powerful illusion because the diversity of successful adaptations in nature may give the impression that the environment perfectly matches them; in reality, it is life that "matches" the always changing environments.
Views About Evolution and/or Creation of Humans, and Responders' Religiosity

Two out of three students from the secular institutions (mean) thought that humans have evolved over hundreds of thousands of years without God's intervention, but almost three out of four students from the religious institution believed that God guided this process (choices A and B, Fig. 10). We did not assess this topic among the faculty (above) but suspect that professors might show response rates comparable to or even higher than the students from the secular institutions. We base this speculation on the fact that faculty response rate to questions about both acceptance of evolution (Questions 1-7 above) and understanding of the evolutionary process (Questions 8-9 above) were consistently more robust than the students'; moreover, polls report that $87 \%$ of members $(n=2,533)$ of the American Association for the Advancement of Science think that humans have evolved without God's intervention (The Pew Research Center for the People \& the Press 2009).

Surprisingly, the rate of agreement with the idea that humans have evolved without God's intervention was 50\% higher among the students from the public and private institutions (mean 65\%, choice A, Fig. 10) than among the U.S. high school biology teachers $(28 \%$, Berkman et al. 2008), whose views coincide with those of our sample of students from the religious institution (29\%). Note that $32 /$ $36 \%$ of the U.S. general public $(n=2,001 / 1,484$; Miller et al. 2006; The Pew Research Center for the People \& the Press 2009), $47 \%$ of the U.S. high school biology teachers (Berkman et al. 2008), and $72 \%$ of our sample of students from the religious institution (choice B, Fig. 10) believe that God guided the process of human evolution.

Interestingly, faculty and students showed a comparable level of religiosity for two of the three questions we asked (choices B, C, Question 11); about 30\% considered religion to be very important in their lives and around $20 \%$ admitted to praying daily (mean combined values choices $\mathrm{B}, \mathrm{C}$, Fig. 11). In contrast, only $5 \%$ of the faculty versus $24 \%$ of the students believed that faith in God is necessary for morality (choice A, Fig. 11). Note that we did not assess Question 11 among the students from the religious institution, but suspect that their rate of agreement with the choices of this question could have been higher than the faculty's and the students' from the secular institutions. We base this speculation on responses to Questions 3 (evolution and creationism are in harmony, choice B, Fig. 3) and 10 (humans have evolved over hundreds of thousands of years but God guided this process, choice B, Fig. 10) where students from the religious institution showed higher response rates than the other groups.

The $30 \%$ of New England faculty and students who thought that religion is important in their lives (above) 
might be comparable to the $33 \%$ of American scientists ( $n=$ 2,533) who admit to believe in God (The Pew Research Center for the People \& the Press 2009), but differs from the $12 \%$ of "professional evolutionary scientists" $(n=149$ members of North American, European, UK, and other countries' National Academies of Sciences; Graffin and Provine 2007) and 7\% of members of the U.S. National Academy of Science $(n=260)$ who believe in a personal God (Larson and Witham 1998). Two recent studies $(n=$ 1,646 Ecklund and Scheitle 2007; $n=1,417$ Gross and Simmons 2009) have also documented that $\approx 30 \%$ of the American professoriat (about 630,000 faculty teaching fulltime at colleges and universities) is religious across institutions and fields, highlighting that researchers in the natural sciences (physics, biology) are less religious than their social sciences counterparts (sociology, economics, history, but except psychology).

\section{Religiosity, Understanding-of-Science and Evolution} Indexes

Three factors seem to determine an individual's acceptance of evolution (Bishop and Anderson 1990; Downie and Barron 2000; Trani 2004; Paz-y-Miño C. and Espinosa 2009a, b, but see Miller et al. 2006; Nadelson and Sinatra 2009): personal religious convictions, understanding the essence of science (method to explore reality) and familiarity with the processes and forces of change in organisms (evolution). Our samples of New England faculty versus students differed clearly in their RI $(\mathrm{Fac}=0.50, \mathrm{Pub}=0.74$, Priv $=0.76)$, SI $(\mathrm{Fac}=2.27, \mathrm{Pub}=1.62$, Priv $=1.58)$, and EI $(\mathrm{Fac}=2.48, \mathrm{Pub}=1.77$, Priv $=1.54)$. In essence, faculty were less religious and more knowledgeable about science and evolution than the students, which might be associated with the higher acceptance of evolution by faculty than by the students $(97 \%$ versus $78 \%$ mean summation choices $\mathrm{A}$ and C, Fig. 6, respectively). Numerous studies have found religiosity and belief to be inversely correlated with acceptance of evolution (Miller et al. 2006; The Gallup Poll 2008, 2009; Nadelson and Sinatra 2009) and positively correlated with scientific literacy, particularly genetics (Miller et al. 2006); however, there is discrepancy about the association between general educational attainment and attitudes toward evolution (Miller et al. 2006; Pigliucci 2007; Nehm and Schonfeld 2007). It is important to emphasize that the religiosity indexes of our samples of faculty and students were three and two times below the U.S. national score $\mathrm{RI}=1.40, n=2,026$ (The Pew Global Attitudes Project 2007), respectively, and that the highly educated New England professors had a level of religiosity comparable to that of the general public in Western Europe, the lowest worldwide (The Pew Global Attitudes Project 2007).
Variables Positively and Negatively Associated with Acceptance of Evolution in the U.S.

The correlation between education level and attitudes toward evolution has been documented in significant studies: public acceptance of evolution in the U.S. increases from the high school $(20 / 21 \%)$, some college $(32 / 41 \%)$, college graduate $(52 / 53 \%)$ to the post-graduate $(65 / 74 \%)$ levels ( $n=\mathrm{NA} / 1,018$; Brumfiel 2005; The Gallup Poll 2009), reaching the highest score among university professors $(97 \%$, this study; choices A+C, Fig. 6). The average acceptance of evolution by the U.S. general public is 35 40\% (Brumfiel 2005; Miller et al. 2006), which coincides with the population attaining only some college education (above). Note that only the post-graduate public and highly educated professors of the U.S. have levels of acceptance of evolution comparable to or higher than the general public in other highly industrialized and prosperous nations like Iceland, Denmark, Sweden, France, Japan, and the UK $(\approx 75-85 \%$; Miller et al. 2006).

Negative attitudes toward evolution in the U.S. reside in specific variables: religious beliefs, pro-life beliefs and political ideology account for most of the variance against evolutionary views (total: nine independent variables), which differ distinctly between the U.S. $\left(R^{2}=0.46\right.$ total effects) and Europe $\left(R^{2}=0.18\right.$ total effects)(Miller et al. 2006; see The Pew Forum on Religion \& Public Life 2008 for detailed statistics on the relationship between religious affiliations and pro-life beliefs, political ideology and evolution); among U.S. educational professionals, decrease in both evolution acceptance and knowledge correlates with increase in religious commitment $(n=337$; Nadelson and Sinatra 2009); conservative Republicans in the U.S. accept evolution less than progressive liberals and independents ( $30 \%$ versus $60 \%$, respectively, $n=1,007$; The Gallup Poll 2007); and frequency of religious practices correlates negatively with acceptance of evolution: $24 \%$ among weekly churchgoers versus $71 \%$ for seldom or never ( $n=$ 1,007; The Gallup Poll 2007).

If attitudes toward evolution by both the general public and highly educated professors correlate, ultimately, with understanding of science/evolution and religiosity/political ideology (positive and negative association of variables, respectively; data above), it follows that robust science education combined with vigorous public debate-where scientific knowledge versus popular belief are constantly discussed - shall increase acceptance of naturalistic rationalism and decrease the negative impact of creationism and ID on "society's evolution literacy." But societal interactions between science and ideology are complex, multifactorial, variable in a spatio-temporal context, and subject to public policy, law, and socio-economic change (Lerner 2000; Moore 2002, 2004; Gross et al. 2005; Apple 
2008; Berkman and Plutzer 2009; Padian and Matzke 2009; Matzke 2010; Wexler 2010).

How can the highly educated professors contribute to strengthen evolution literacy? (1) By being proactive rather than reactive in confronting the "anti-evolution wars" (Ruse 2001; Pigliucci 2007; Berkman and Plutzer 2009). If in Northeastern U.S. acceptance of evolution is only $59 \%$, the highest nationwide (The Pew Research Center for the People \& the Press 2005), and if $91 \%$ of the New England faculty are either very concerned $(64 \%)$ or somehow concerned $(27 \%)$ about the controversy of evolution versus creationism versus ID and its implications for science education (data this study), it is imperative that the university professors reach out to the public and lead the debate over science education and evolution literacy. (2) By persuading the education departments at their institutions to fortify science training of future educators: highereducation and outreach programs in science, particularly biology, for school teachers are fundamental to integrate evolution into our society's culture (Paz-y-Miño C. and Espinosa 2009a, b). Biology school teachers in the U.S. rely on poor-to-excellent evolution state education standards that guide their teaching practices (Mead and Mates 2009; for a historical account of these types of assessments, see Moore 2002; Lerner 2000, 2006). Instructors' personal views of evolution however seem to influence the quality of schooling more than states' guidelines: $14-69 \%$ of school teachers $(n=15$ states in the U.S.) question or reject evolution, and even teach supernatural causation in science classes (Moore 2002; additional statistics above); $43 \%$ of high school teachers are willing to dedicate "equal time" to science and ID (National Science Foundation 2006), and 30\% admit to having omitted evolution from their lessons or including nonscientific substitutes to evolution in their classes due to pressure (U.S. National Science Teachers Association 2005). Notably, high school biology teachers' acceptance of evolution also increases with conceptual understanding of evolutionary theory attained during their own college or graduate school training (concept-map studies, Rutledge and Mitchell 2002; but see Nehm and Schonfeld 2007). (3) By changing the emphasis with which college science is taught and improving the science curriculum: it is easier and faster to change the perspectives with which a course is taught than to modify the university/college curriculum; however, both might be indispensable to improving positive attitudes toward science and evolution. We have documented that acceptance of evolution at representative New England colleges is higher among biology majors $(66 \%, n=449)$ than nonmajors $(46 \%, n=382)$ and that it increases gradually among biology majors from the freshman $(58 \%, n=163)$ to the senior $(80 \%, n=95)$ year, due to exposure to upperdivision courses with evolutionary content (Paz-y-Miño C. and Espinosa 2009a, b); however, graduating nonmajors only reach a level of acceptance of evolution below that of the recently arrived-to-college freshman biology majors (54\%, $n=680$; Paz-y-Miño C. and Espinosa, unpublished data). Note that after changing the emphasis with which the introductory biology courses were taught at one of our sample institutions (UMassD) via a comprehensive evolutionary approach in both lectures and laboratories, students increased their acceptance of evolution from $61 \%$ (mean value, $n=214$, September 2008/2009) to $84 \%$ (mean value, $n=174$, April 2009/May 2010) during the freshman year alone (Paz-y-Miño C. and Espinosa, unpublished data). Due to the disparity in acceptance of evolution between biology majors and nonmajors, and the level of knowledge about evolution with which each group graduates from college, we have recommended that evolutionary theory should be offered widely and taught without distinction between biology majors and nonmajors as part of their science literacy (Paz-y-Miño C. and Espinosa 2009a, b). (4) By creating a new type of professorship position: "professor for the public understanding of science," whose exclusive role shall be to explain to the public the significance of the research conducted by each discipline (see Pigliucci 2007), and also by assigning the most reputable professors and best communicators of science to the large-lecture courses, usually attended by nonscience majors. The latter is successfully practiced at several of the elite U.S. universities and colleges. (5) By constantly surveying variations in attitudes toward science and evolution among faculty, students and staff, and coordinating immediate responses to emerging antievolutionism: contrary to the assumption that skepticism toward creationist views predominates in academia, recent studies (Ecklund and Scheitle 2007; Gross and Simmons 2009) demonstrate that U.S. university professors, even at prestigious research institutions, increasingly embrace religiosity, a factor negatively correlated with acceptance of evolution (Miller et al. 2006; The Gallup Poll 2007, 2008, 2009; Nadelson and Sinatra 2009; this study); it is, therefore, conceivable to forecast a probable decline in acceptance of evolution by university professors, but this prediction needs to be verified longitudinally. (6) By sponsoring in- and off-campus lecture series, workshops and debates, open to the local high school teachers and the public, where university professors of all disciplines examine the anti-evolution phenomena, learn about the limitations established by schools boards on the science school curriculum and orient the audience on how to communicate modern science to all (Paz-y-Miño C. and Espinosa 2009b). Workshopdiscussion modules on "why evolution matters" can be particularly effective when organized for school board members, school district administrators, science teachers and university professors (for exemplar case see Johnson et al. 2009). (7) By actively pursuing participation in "town 
halls for scientists and public" to discuss issues related to scientific research and the controversy of evolution versus creationism versus ID. Surprisingly, only $24 \%$ of U.S. scientists are aware of these meetings, which are often organized around the nation; the detachment of scientists from the public is concerning: $48 \%$ admit to talk with nonscientists occasionally (The Pew Research Center for the People \& the Press 2009). (8) By organizing multidisciplinary teams of professors (anthropology, biology, education, ethics, history, law, philosophy, political science, social psychology, and religious studies) committed to advice community groups on theoretical and practical aspects of civil action to counter anti-evolution campaigns, anti-intellectualism tendencies, and pro creationism and ID agendas (Young and Edis 2004; Petto and Godfrey 2007; Coalition of Scientific Societies 2008; Williams 2009). (9) By never underestimating the influence of the anti-evolution movements that grow strong among misinformed citizens, vary in impact geographically, and benefit from the frequent disconnect between scientists and society. Indeed, the regional differential acceptance of evolution in the U.S. (i.e., Northeast 59\%, Northwest $57 \%$, Midwest 45\%, South 38\%; The Pew Research Center for the People \& the Press 2005) suggests that pro-evolution campaigns shall require strategies compatible with local idiosyncrasies. (10) By including in the "broad impact" section of research grant applications specific multidisciplinary outreach modules to educate the public in the areas of scientific literacy, "on-the-job-training” workshops for local/ regional high school teachers, online-mini courses, online assessment of local/regional attitudes toward science/evolution, laboratory internships and field work. The National Science Foundation, U.S. Department of Education, and private donors encourage and even require grant applicants to reach out to the public in meaningful areas of current interest and societal debate.

\section{Relevance of This Study}

This is the first comprehensive study to summarize the views of 244 highly educated faculty $(90 \%$ Ph.D. holders in 40 disciplines), affiliated with 35 academic institutions (public, private, and religious), widely distributed geographically in New England (states of Connecticut, Maine, Massachusetts, New Hampshire, Rhode Island, and Vermont), who were polled in three areas: (1) their perspectives about the controversy of evolution versus creationism versus ID, (2) their understanding of how the evolutionary process works, and (3) their personal convictions concerning the evolution and/or creation of humans in the context of the faculty's own religiosity. Our survey was conducted in one of the most progressive and intellectual regions in the U.S., where public acceptance of evolution is the highest nationwide (59\%). Although we found high levels of acceptance of evolution among the New England professors, plus good conceptual understanding of the evolutionary process (with the exception that $30 \%$ had a Lamarckian view of evolution) and the controversy between scientific knowledge and popular belief, we detected surprisingly high religiosity $(30 \%)$. After comparing and contrasting our data with significant national and international statistics, we conclude that attitudes toward evolution might correlate, ultimately, with understanding of science/evolution (positive association of variables) and religiosity/political ideology (negative association of variables), and that science education combined with vigorous public debate shall increase acceptance of naturalistic rationalism and decrease the negative impact of creationism and ID on "society's evolution literacy." We identified specific areas of action where university professors' contribution to the proevolution movement is indispensable.

Acknowledgments We thank the departments of Biology at UMassD, RWU, and PC, and their students, faculty, and administrators for contributing to this study. Lauren Murray compiled part of the email data base of New England faculty and contributed to overseeing the online surveying, Joyce Rosinha coordinated the email distribution of surveys to students at UMassD; Nicanor Austriaco and the BioSociety supported this initiative at PC. Patricia Kennedy, Patricia Pimental and Julie Coccia facilitated logistics. Gregory Rogers, Kristen Procopio, and Julie Coccia provided part of the data to build Table 2. The Human Subjects/Institutional Review Boards at UMassD, RWU and PC approved the protocols. G. Paz-y-Miño C. is supported by the UMassD Office of Faculty Development (Innovation in Teaching Awards AY0910 and Undergraduate Research Grants F09) and A. Espinosa by NIH-NCRR grant \#2 P20RR16457-04. Two reviewers provided comments that helped us improve the manuscript.

\section{References}

Apple MW. Evolution versus creationism in education. Educ Policy. 2008;22:327-35.

Berkman MB, Sandell-Pacheco H, Plutzer E. Evolution and creationism in America's classrooms: a national portrait. PLoS Biol. 2008;6:920-4.

Berkman MB, Plutzer E. Scientific expertise and the culture war: public opinion and the teaching of evolution in the American states. Perspective on Politics. 2009;7:485-99.

Bishop BA, Anderson CW. Student conceptions of natural selection and its role in evolution. J Res Sci Teach. 1990;27:415-27.

Brumfiel G. Who has designs on your students' minds? Nature. 2005; $434: 1062-5$

Coalition of Scientific Societies. Evolution and its discontents: a role for scientists in science education. FASEB J. 2008;22:1-4.

Cornish-Bowden A, Cárdenas ML. The threat from creationism to the rational teaching of biology. Biol Res. 2007;40:113-22.

Coyne JA. Why evolution is true. Oxford: Oxford University Press; 2009.

Dawkins R. The greatest shown on earth: the evidence for evolution. New York: Free Press; 2009.

Donnelly LA, Boone WJ. Biology teacher's attitudes toward and use of Indiana's evolution standards. J Res Sci Teach. 2007;44:236-57.

Downie JR, Barron NJ. Evolution and religion: attitudes of Scottish first year biology and medical students to the teaching of evolutionary biology. J Biol Educ. 2000;34:140-6. 
Ecklund EH, Scheitle CP. Religion among academic scientists: distinctions, disciplines, and demographics. Soc Probl. 2007;54:289-307.

Forrest B, Gross PR. Creationism's Trojan horse: the wedge of intelligent design. New York: Oxford University Press; 2007a.

Forrest BC, Gross PR. Biochemistry by design. Trends Biochem Sci. 2007b;32:301-10.

Forrest B. It's déjà vu all over again: the intelligent design movement's recycling of creationist strategies. Evolution: Education and Outreach. 2010;3:170-82.

Graffin GW, Provine WB. Evolution, religion and free will. Am Sci. 2007;95:294-7.

Gross N, Simmons S. The religiosity of American college and university professors. Sociol Relig. 2009;70:101-29.

Gross PR, Goodenough U, Haack S, Lerner LS, Schwartz M, Schwartz R. The state of state science standards. Washington DC: Thomas B. Fordham Institute; 2005.

Hokayem H, BouJaoude S. College students' perceptions of the theory of evolution. J Res Sci Teach. 2008;45:395-419.

Johnson JB, Adair M, Adams BJ, Fairbanks DJ, Itamura V, Jeffrey DE, et al. Evolution Education in Utah: a state office of education-university partnership focuses on why evolution matters. Evolution: Education and Outreach. 2009;2:349-58.

Kitzmiller et al. versus Dover Area School District et al. 2005. http:// www.pamd.uscourts.gov/kitzmiller/kitzmiller 342.pdf. Accessed November 30, 2010

Larson EJ, Witham L. Leading scientists still reject God. Nature. 1998;394:313

Lerner LS. Good science, bad science: teaching evolution in the States. Washington DC: The Thomas B. Fordham Foundation; 2000.

Lerner LS. Good, bad, and lots of indifferent: the state of State K-12 science standards and the fate of US science education. Freethought Today, 23, Freedom From Religion Foundation Inc.2006. http://www.ffrf.org/publications/freethought-today/articles/GoodBad-and-Lots-of-Indifferent-The-State-of-State-K-12-ScienceStandards-/. Accessed November 30, 2010.

Matzke NJ. The evolution of creationist movements. Evolution: Education and Outreach. 2010;3:145-62.

Mayr E. What evolution is. New York: Basic Books; 2001.

Mead LS, Mates A. Why science standards are important to a strong science curriculum and how states measure up. Evolution: Education and Outreach. 2009;2:359-71.

Miller JD, Scott EC, Okamoto S. Public acceptance of evolution. Science. 2006;313:765-6.

Miller KR. Falling over the edge. Nature. 2007;447:1055-6.

Miller KR. Only a theory: evolution and the battle for America's soul. New York: Viking Penguin; 2008.

Moore R. Teaching evolution: do state standards matter? Bioscience. 2002;52:378-81.

Moore R. How well do biology teachers understand the legal issues associated with the teaching of evolution? Bioscience. 2004:54:860-65.

Moore R. What are students taught about evolution? McGill J Educ. 2007;42:177-87.

Moore R, Kraemer K. The teaching of evolution and creationism in Minnesota. Am Biol Teach. 2005;67:457-66.

Nadelson LS, Sinatra GM. Educational professionals' knowledge and acceptance of evolution. Evolutionary Psychology. 2009;7:490-516.

National Science Foundation. Science and technology: public attitudes and understanding. In: Science and engineering indicators, Chapter 7; 2006. p. 7.1-7.46

Nehm RH, Schonfeld IS. Does increasing biology teacher knowledge of evolution and the nature of science lead to greater preference for the teaching of evolution in schools? J Sci Teach Educ. 2007;18:699-723.
Padian K. The evolution of creationists in the United States: where are they now, and where are they going? C R Biologies. 2009;332:100-9.

Padian K, Matzke N. Darwin, Dover, 'intelligent design' and textbooks. Biochem J. 2009;417:29-42.

Paz-y-Miño CG, Espinosa A. Assessment of biology majors versus non-majors views on evolution, creationism and intelligent design. Evolution: Education and Outreach. 2009a;2:75-83.

Paz-y-Miño CG, Espinosa A. Acceptance of evolution increases with student academic level: a comparison between a secular and a religious college. Evolution: Education and Outreach. 2009b;2:65575.

Petto AJ, Godfrey LR, editors. Scientists confront intelligent design and creationism. New York: W. W. Norton and Company; 2007.

Phy-Olsen A. Evolution, Creationism, and Intelligent Design. Historical Guides to Controversial Issues in America. Santa Barbara: Greenwood; 2010.

Pigliucci M. The evolution-creation wars: why teaching more science just is not enough. McGill J Educ. 2007;42:285-306.

Ruse M. The evolution wars: A guide to the debates. New Jersey: Rutgers University Press; 2001.

Rutledge ML, Mitchell MA. High school biology teachers' knowledge structure, acceptance and teaching of evolution. Am Biol Teach. 2002;64:21-8.

Scott EC. Evolution vs. creationism: an introduction. 2nd ed. Westport: Greenwood Press; 2009.

Sieger S, Castellan NJ. Nonparametric statistics for the behavioral sciences. Boston: McGraw Hill; 1988.

The Gallup Poll. Majority of Republicans Doubt Theory of Evolution. 2007. http://www.gallup.com/poll/27847/Majority-RepublicansDoubt-Theory-Evolution.aspx. Accessed November 30, 2010.

The Gallup Poll. Evolution, creationism, intelligent design. 2008. http:// www.gallup.com/poll/21814/Evolution-Creationism-IntelligentDesign.aspx. Accessed November 30, 2010.

The Gallup Poll. On Darwin's Birthday, Only 4 in 10 Believe in Evolution. 2009. http:/www.gallup.com/poll/114544/DarwinBirthday-Believe-Evolution.aspx. Accessed November 30, 2010.

The Pew Forum On Religion \& Public Life. US religious landscape survey-religious beliefs and practices: diverse and politically relevant. Washington DC. 2008. http://religions.pewforum.org/ pdf/report-religious-landscape-study-full.pdf. Accessed November 30, 2010.

The Pew Global Attitudes Project. World publics welcome global trade but not immigration. Washington DC. 2007. http://pewglobal.org/ files/pdf/258.pdf. Accessed November 30, 2010.

The Pew Research Center for the People \& the Press. Public divided on origins of life: religion a strength and weakness for both parties. Washington DC. 2005. http://people-press.org/reports/pdf/254.pdf. Accessed November 30, 2010.

The Pew Research Center for the People \& the Press. Scientific achievements less prominent than a decade ago: public praises science; scientists fault public, media. Washington DC. 2009. http://peoplepress.org/reports/pdf/528.pdf; 2009. Accessed November 30, 2010.

Trani R. I won't teach evolution; it's against my religion. And now for the rest of the story.... Am Biol Teach. 2004;66:419-27.

US National Science Teachers Association. Survey indicates science teachers feel pressure to teach nonscientific alternatives to evolution. 2005. http://science.nsta.org/nstaexpress/nstaexpress 2005_03_28_pressrelease.htm. Accessed November 30, 2010.

Wexler JD. From the classroom to the courtroom: intelligent design and the constitution. Evolution: Education and Outreach. 2010;3:215-24.

Williams JD. Belief versus acceptance: why do people do not believe in evolution? BioEssays. 2009;31:1255-62.

Young M, Edis T, editors. Why intelligent design fails: a scientific critique of the new creationism. New Brunswick: Rutgers University Press; 2004. 